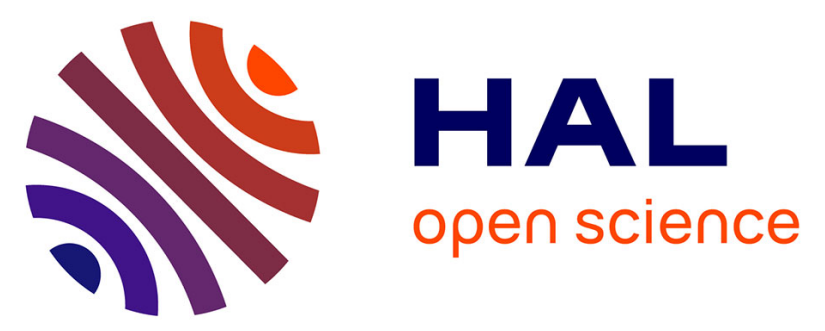

\title{
Reconciling Cretaceous paleomagnetic and marine magnetic data for Iberia: New Iberian paleomagnetic poles
}

M. Neres, E. Font, J. M. Miranda, Pierre Camps, P. Terrinha, J. Mirao

\section{- To cite this version:}

M. Neres, E. Font, J. M. Miranda, Pierre Camps, P. Terrinha, et al.. Reconciling Cretaceous paleomagnetic and marine magnetic data for Iberia: New Iberian paleomagnetic poles. Journal of Geophysical Research, 2012, 117, pp.B06102. 10.1029/2011JB009067 . hal-00758103

\section{HAL Id: hal-00758103 \\ https://hal.science/hal-00758103}

Submitted on 21 Oct 2020

HAL is a multi-disciplinary open access archive for the deposit and dissemination of scientific research documents, whether they are published or not. The documents may come from teaching and research institutions in France or abroad, or from public or private research centers.
L'archive ouverte pluridisciplinaire HAL, est destinée au dépôt et à la diffusion de documents scientifiques de niveau recherche, publiés ou non, émanant des établissements d'enseignement et de recherche français ou étrangers, des laboratoires publics ou privés. 


\title{
Reconciling Cretaceous paleomagnetic and marine magnetic data for Iberia: New Iberian paleomagnetic poles
}

\author{
M. Neres, ${ }^{1}$ E. Font, ${ }^{1}$ J. M. Miranda, ${ }^{1}$ P. Camps,${ }^{2}$ P. Terrinha,${ }^{3}$ and J. Mirão ${ }^{4}$ \\ Received 29 November 2011; revised 16 April 2012; accepted 19 April 2012; published 6 June 2012.
}

[1] The Cretaceous paleogeography and the kinematic evolution of the Iberian plate are poorly constrained. Especially problematic is to reconcile Iberian paleomagnetic data with paleomagnetic data of the neighboring plates and with Euler poles derived from seafloor magnetic anomalies. The first limitation arises from the Cretaceous Normal Polarity Superchron where paleogeographic reconstruction using marine magnetic anomalies is handicapped. The second arises from the paucity of reliable paleomagnetic poles with satisfactory statistical criteria and age. In order to address these shortcomings and provide new high quality paleomagnetic poles for Iberia, we conducted a detailed rock magnetic and paleomagnetic study of two Cretaceous magmatic sills, the Paço de Ilhas (PI) and Foz da Fonte (FF) sills, from the Lusitanian Basin, Portugal, recently dated at about 88 and $94 \mathrm{Ma}$, respectively. Our results show that the magnetic mineralogy of the sills is primary, i.e., acquired during magma cooling, and essentially represented by titanomagnetite.

The corresponding paleomagnetic poles match the synthetic APWP from the African plate at 80 and $100 \mathrm{Ma}$. On the basis of a rigorous selection of Iberian Cretaceous poles, we then calculated mean paleomagnetic poles for different time intervals and found that Iberian paleomagnetic data fit well the global APWP between 70 and $120 \mathrm{Ma}$, but move far away from the APWP at pre-rift times. Our approach shows that new and better constrained paleomagnetic poles can aide in solving part of the contradiction between Iberian and African APWPs.

Citation: Neres, M., E. Font, J. M. Miranda, P. Camps, P. Terrinha, and J. Mirão (2012), Reconciling Cretaceous paleomagnetic and marine magnetic data for Iberia: New Iberian paleomagnetic poles, J. Geophys. Res., 117, B06102, doi:10.1029/2011JB009067.

\section{Introduction}

[2] The break-up of the Pangaean supercontinent and subsequent kinematic evolution of major plates during Mesozoic times are now well constrained by paleomagnetic data [Besse and Courtillot, 2002; Schettino and Scotese, 2005; Torsvik et al., 2008] and oceanic magnetic anomalies [Le Pichon and Sibuet, 1971; Luis and Miranda, 2008; Olivet, 1996; Russell and Whitmarsh, 2003; Sibuet et al., 2004; Srivastava et al., 2000, 1990a, 1990b]. However, the positions of minor blocks, such as Iberia, are still poorly constrained [e.g., Márton et al., 2004; Osete and Palencia Ortas, 2006; Osete et al., 2011]. Nonetheless, the Iberian Plate occupies a strategic, pivotal position during opening of the Atlantic Ocean and the Bay of Biscay. Understanding its

\footnotetext{
${ }^{1}$ IDL, Universidade de Lisboa, Lisbon, Portugal.

${ }^{2}$ Géosciences Montpellier, CNRS, Université Montpellier 2, Montpellier, France.

${ }^{3}$ Laboratório Nacional de Energia e Geologia, IDL, Lisbon, Portugal.

${ }^{4}$ Laboratório HERCULES, Évora, Portugal.

Corresponding author: M. Neres, IDL, Faculdade de Ciencias da Universidade de Lisboa, Edifício C8, Campo Grande, 1749-016 Lisboa, Portugal. (neresmarta@gmail.com)

Copyright 2012 by the American Geophysical Union. 0148-0227/12/2011JB009067
}

kinematic evolution is important for a number of reasons, including resource and natural hazard assessment [Cloetingh et al., 2011; Omira et al., 2011]. Several models based on oceanic magnetic anomalies have been proposed where the data are merged into a single rotation event of about $37^{\circ}$ counterclockwise, and associated with Bay of Biscay seafloor spreading between the chrons M0 (125 Ma) and C33r (83 Ma) [Rosenbaum et al., 2002; Sibuet et al., 2004; Srivastava et al., 1990a; Vissers and Meijer, 2012]. A single rotation phase of Iberia is also supported by paleomagnetic data [Gong et al., 2008a; van der Voo, 1969], while some favor a discontinuous two-stage counterclockwise rotation model [Galdeano et al., 1989; Moreau et al., 1997], and others a succession of clockwise and counterclockwise rotations [Storetvedt et al., 1990, 1987].

[3] When evaluating proposed models, the major limitation resides in our incapacity to reconcile the paleomagnetic data with the corresponding eulerian finite rotation poles within a unique and consistent kinematic model. The relative motion between Iberia and Africa cannot be directly deduced from marine magnetic anomalies, so it must be deduced from the relative motion of each plate relative to the North American plate, data that can be readily obtained from the magnetic striping of the North and Central Atlantic [e.g., Labails et al., 2010; Luis and Miranda, 2008]. In spite of 
small differences mainly related to early drifting stages, the kinematics of the Central Atlantic are well known. However, identification of pre-M0 magnetic anomalies along the western Iberian margin has been the source of major uncertainties. Some authors have identified magnetic chrons up to M17 along the Iberian margin [e.g., Srivastava et al., 2000], with oceanic spreading beginning as early as 143 Ma. Others argue that only after chron M0r [Olivet, 1996], or chrons CM4n-M5r [Russell and Whitmarsh, 2003], was normal oceanic spreading initiated. In addition, the long-lived Cretaceous Normal Polarity Superchron (CNPS) prevented the development of normal and reverse magnetic periods during that time, thus limiting the study of plate kinematics with magnetic methods.

[4] The Cretaceous paleomagnetic database for Iberia is still poorly constrained and requires revisions in (1) age dating, (2) statistical criteria, (3) tilt or shallowing inclination correction in the case of records from sedimentary rocks, and (4) adjustments due to the influence of local/regional remagnetizations. Uncertainties in age result from low temporal resolution and outdated radiometric data. The reference paleomagnetic poles for the Lusitanian and Algarve basins, for example, are computed from a limited number of paleomagnetic sites for which the ages of the samples encompasses a large interval of time, particularly for those contemporaneous with a major rifting phase during the Barremian-Aptian and Aptian-Albian [Galdeano et al., 1989; Moreau et al., 1997]. In addition, misfits in paleopole ages and positions have resulted from outdated methods including $\mathrm{K} / \mathrm{Ar}$ measurements on whole rock samples that can be biased by excess/loss of Ar during alteration. One serious problem is the widely documented remagnetization for northern Iberian sites [Dinarès-Turell and Garcia-Senz, 2000; Gong et al., 2008a, 2009; Juárez et al., 1998, 1994; Moreau et al., 1992; Schott and Peres, 1987; Steiner et al., 1985; Villalain et al., 2003], and sites in the Algarve and Lusitanian basins [Galbrun et al., 1990; Galdeano et al., 1989]. These remagnetized sites are usually found in Aptian-Albian times, during the final rifting phase that affected the west Iberian continental lithosphere. Except for late Cretaceous magmatic complexes (Sintra, Sines and Monchique [van der Voo, 1969], and Lisbon Volcanics [van der Voo and Zijderveld, 1971]), the Apparent Polar Wander Path (APWP) for Iberia is essentially based on sedimentary rocks, which are more sensitive to remagnetization effects and for which, in most cases, shallowing inclination corrections and field tests are lacking. Therefore, new reliable paleomagnetic poles, together with accurate radiometric ages, field tests, and evaluation of the magnetic mineralogy of samples are required to update and better constrain the Cretaceous Iberian APWP.

[5] Here, we present a detailed paleomagnetic investigation of two large Cretaceous magmatic sills, the Paço de Ilhas and Foz da Fonte sills, in the Lusitanian Basin, which were dated by $\mathrm{U}-\mathrm{Pb}$ and ${ }^{40} \mathrm{Ar}{ }^{39} \mathrm{Ar}$ methods at $\sim 88$ and $\sim 94$ Ma, respectively [Grange et al., 2010; Mahmoudi, 1991; Miranda et al., 2009]. Detailed magnetic mineralogy analyses coupled to scanning microscopic observations suggest a primary (i.e., during cooling) origin for the characteristic magnetic remanence carried by these rocks. Our new, high quality paleomagnetic poles allow us to calibrate the APWP for Iberia during the late Cretaceous. We have compared these results to the recent global APWP of Torsvik et al. [2008], by rotating the new poles into African coordinates using late Cretaceous Euler poles that were deduced independently from seafloor marine magnetic anomalies for two plate pairs, Iberia-North America, and Africa-North America. The good agreement between our rotated poles and the global APWP can be considered a reliability test for the paleomagnetic data, because the period under analysis is reasonably well constrained by identifiable seafloor magnetic chrons in the North and Central Atlantic. Implications for the kinematic evolution of Iberia during the Cretaceous are discussed.

\section{Geological Settings}

[6] The Paço d'Ilhas (PI; dated at $88 \mathrm{Ma}$ ) and Foz da Fonte (FF; dated at $94 \mathrm{Ma}$ ) sills were emplaced in the internal part of the Lusitanian Basin, the least extended domain of the West Iberia Margin that formed as a consequence of lithospheric rifting between Iberia and North America. According to various studies [e.g., Afilhado et al., 2008; Neves et al., 2009; Sibuet et al., 2007; Tucholke et al., 2007], the West Iberia Margin is a non-volcanic rifted continental margin that has been sub-divided into three zones that are characterized as (1) thinned continental crust (approximately $100 \mathrm{~km}$ wide), (2) a transitional zone (approximately $200 \mathrm{~km}$ wide), and (3) normal oceanic crust. From a structural and compositional point of view, Zone 1 displays the pinch-out of the lower crust and a series of upper crustal basement grabens and half-grabens filled with proximal and hemi-pelagic sediments resulting from significant vertical motion in the crust. Zone 2 was intruded during the early Cretaceous by late syn-rifting, and in the Late Cretaceous by post-rifting alkaline basalts. Zone 3 represents a highly stretched crust dominated by Mantle exhumation and serpentinization. The initial age of seafloor spreading is still debated. Sibuet et al. [2007] and Tucholke et al. [2007] favor two main rifting events, (1) widespread early rifting during Late Triassic and Early Jurassic times, and (2) Late Jurassic through Early Cretaceous rifting and Continental mantle exhumation localized in the transitional zone, and that seafloor spreading actually started sometime in the Aptian-Albian transition. However, Bronner et al. [2011] argue that alkaline volcanism in the transitional zone is syn-rifting and that the oceanic spreading is Late Cretaceous in age.

[7] Studies of the Lusitanian and Algarve Basins have allowed the identification of the following three magmatic pulses: (1) Tholeiitic volcanism of earliest Jurassic age as the northernmost manifestation of the Central Atlantic Magmatic Province [Martins et al., 2008; Verati et al., 2007]; (2) A magmatic pulse of alkaline transitional composition occurs as scattered small-scale plugs and sills of Late Jurassic age [Grange et al., 2008; Martins, 1991]; (3) the Late Cretaceous alkaline magmatic event comprising the igneous intrusive complexes of Sintra (84-79 Ma) [Macintyre and Berger, 1982; Miranda et al., 2009; Storetvedt et al., 1987], Sines (75 Ma) [Miranda et al., 2009], Monchique (72 Ma) [Bernard-Griffiths et al., 1997; Miranda et al., 2009; Rock, 1982], and the Lisbon volcanic complex (73 Ma) [Ferreira and Macedo, 1979] (Figure 1a). The PI and FF sills are two of several scattered sub-volcanic 

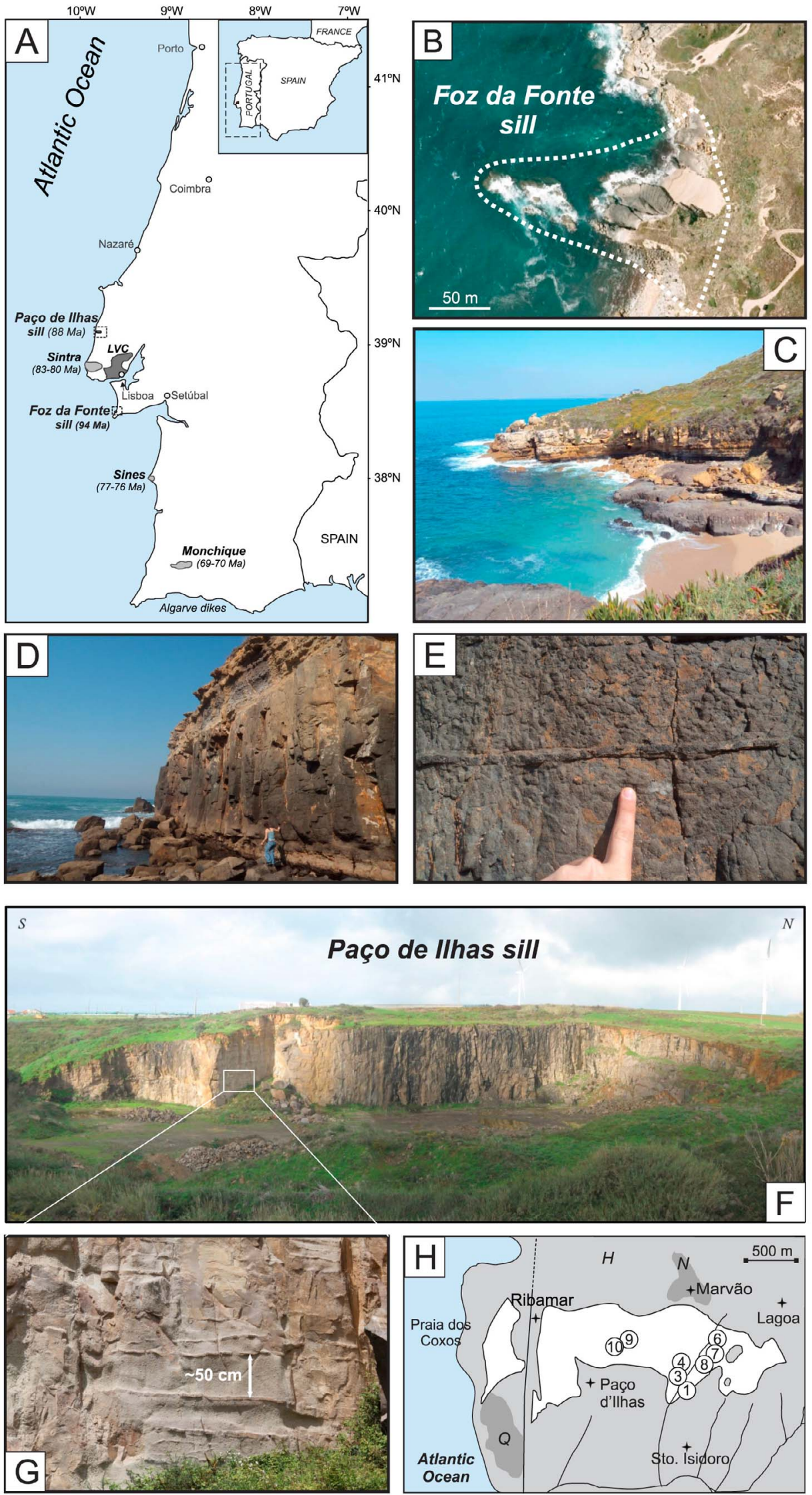

Figure 1 
intrusions that belong to this third event [Miranda, 2010; Miranda et al., 2009], and were emplaced into Lower Cretaceous shallow marine sediments.

[8] Revised radiometric ages were recently published for Late Cretaceous magmatism in the Lusitanian Basin and provide us with excellent candidates for new paleomagnetic investigations [Grange et al., 2010; Miranda, 2010; Miranda et al., 2009]. The Paço de Ilhas sill was dated at $88.0 \pm 2.7 \mathrm{Ma}$ and $86.8 \pm 2.5 \mathrm{Ma}$, using $\mathrm{K}$-Ar on biotite and K-feldspar respectively [Mahmoudi, 1991], and at $88.3 \pm 0.5 \mathrm{Ma}$ based on U-Pb on zircon [Grange et al., 2010]. This sill is a kilometer-scale magmatic body that crops out near the town of Ribamar (Figure 1f). It comprises monzogabbro and monzonite for which geochemical and petrographic features were extensively described by Miranda [2010]. The maximum thickness of the sill exceeds $20 \mathrm{~m}$, although the contact with underlying sediments is not observable (Figure 1d). The presence of syenitic sheets, that resulted from fractional crystallization, indicates several successive magmatic pulses (Figure 1e) [Mahmoudi, 1991]. The PI sill intrudes upper Hauterivian (133-130 Ma) mixed sediments (carbonates and sandstone) [Dinis et al., 2008]. Because sills are intruded along the horizontal stratification plane of the host sediments, no tilt correction was done.

[9] The Foz da Fonte sill was recently dated at $93.8 \pm 3.9$ Ma using the ${ }^{40} \mathrm{Ar} /{ }^{39} \mathrm{Ar}$ method on amphibole [Miranda et al., 2009]. It is a massive $10 \mathrm{~m}$ thick dolerite, cropping out along Foz Beach, $4.5 \mathrm{~km}$ kilometers north of Cabo Espichel (Figures $1 \mathrm{~b}$ and 1c). It intrudes upper Albian (102-99.6 Ma) limestones and claystones [Dinis et al., 2008]. The geographic extension of the FF sill is difficult to evaluate in the field because it gently dips toward the NNW and is cut by a fault to the SSE (Figure 1c). The structural surface (strike) of the sill is oriented $\mathrm{N} 230^{\circ}$ and gently dips $\sim 10^{\circ}$ toward the north.

\section{Sampling and Methods}

[10] Samples were collected in the field with a gasolinepowered rock drill and oriented using a magnetic compass. In the PI sill, 80 oriented cylinders were collected at eight sites within an area of about $1 \mathrm{~km}$ (Figure 1f). In the FF sill, 50 oriented cylinders were collected along the center and at the margin of the outcropping body. Geographical coordinates for the PI and FF sites are listed in Table S3 in the auxiliary material. ${ }^{1}$ In the laboratory, samples were cut into standard paleomagnetic specimens, which then have been treated using thermal and alternating field (AF) demagnetization and measured with a JR6 spinner magnetometer. AF demagnetization results were processed with a LDA-3A demagnetizer (AGICO). Thermal treatments were performed

\footnotetext{
${ }^{1}$ Auxiliary materials are available in the HTML. doi:10.1029/ 2011JB009067.
}

within a prototype-shielded furnace. Characteristic Remanent Magnetizations (ChRM) were calculated by principal component analysis [Kirschvink, 1980] and Fisher [1953] statistics using the Remasoft software [Chadima and Hrouda, 2006].

[11] Our understanding of the remanence carriers in the rocks is based on Isothermal Remanent Magnetization (IRM) analyses, triaxial IRM thermal demagnetization [Lowrie, 1990], temperature dependence of magnetic susceptibility, First Order Reversal Curve (FORC) measurements as well as petrographic and Scanning Electron Microscopic (SEM) observations coupled to Energy Dispersive Spectra analyses (SEM-EDS). IRM was induced up to $1.2 \mathrm{~T}$ using an impulse magnetizer IM-10-30 (ASC Scientific) and data were subsequently treated by fit of cumulative log-Gaussian functions [Kruiver et al., 2001; Robertson and France, 1994]. IRM triaxial demagnetization [Lowrie, 1990] was performed after IRM acquisition at 1.4, 0.4 and $0.12 \mathrm{~T}$ fields along specimen $\mathrm{z}, \mathrm{y}$ and $x$ axis, respectively. Samples were then thermally demagnetized and remanence was measured at each step with a JR6 magnetometer. NRM:IRM data were developed after Fuller et al. [2002]. IRM was induced in a $100 \mathrm{mT}$ peak field and subsequently demagnetized at the same steps as used during demagnetization of the natural remanent magnetization (NRM). Thermomagnetic susceptibility was measured at low and high temperature in an Ar atmosphere using a CS-L cryostat apparatus and a CS4 furnace in a MFK1 Kappabridge (AGICO). Hysteresis and FORC measurements were performed at room temperature on selected samples with the Micro Vibrating Sample Magnetometer at the Institute of Geophysic, UNAM, Mexico, and treated with the FORCinel software package [Harrison and Feinberg, 2008]. Microscopic observations in reflected light were performed on polished thin sections prepared from specimens cut from the cylinder cores. We used a Leitz orthoplan microscope located in the Laboratory of Géosciences, Montpellier (France), that allows maximum magnification under oilimmersion of $1250 \times$. SEM observations and EDS analyses were performed on carbon-coated rock fragments using a Hitachi S-3700N coupled to an EDS Bruker XFlash ${ }^{\circledR} 5010$ in the Hercules Laboratory, Évora (Portugal), and a Jeol JSM-6360LV coupled to a Noran EDS analyzer from in GET Laboratory, Toulouse (France).

\section{Results}

\subsection{Paço de Ilhas (PI)}

\subsubsection{PI Paleomagnetism}

[12] A total of 280 specimens were analyzed, 208 of these were AF and 67 were thermally demagnetized. Of the samples treated, 275 yielded stable demagnetization patterns at high fields and high temperatures (Table S1 in the auxiliary material). Zijderveld diagrams show two magnetic

\footnotetext{
Figure 1. (a) Geological setting of the Paço de Ilhas (PI) and Foz da Fonte (FF) sills. Major Late Cretaceous magmatic events are also indicated. (b) Satellite photography (Google Earth) of the FF sill (white dashed lines show the emerged part of the sill). (c) Field photograph of the FF sill cropping out at Foz Beach ( $\left.38^{\circ} 27^{\prime} 3.5^{\prime \prime} / 9^{\circ} 12^{\prime} 5.5^{\prime \prime}\right)$. (d) Cross-section of the FF sill containing (e) magmatic joins. (f) PI sill (sites PI3 and PI4; $39^{\circ} 0^{\prime} 0^{\prime} / 9^{\circ} 24^{\prime} 3^{\prime \prime}$ ). (g) Syenite levels indicating several magmatic injections. (h) Simplified geological map of the PI sill with location of the sampled sites (H indicates Hauterivian and Q Quaternary sediments).
} 

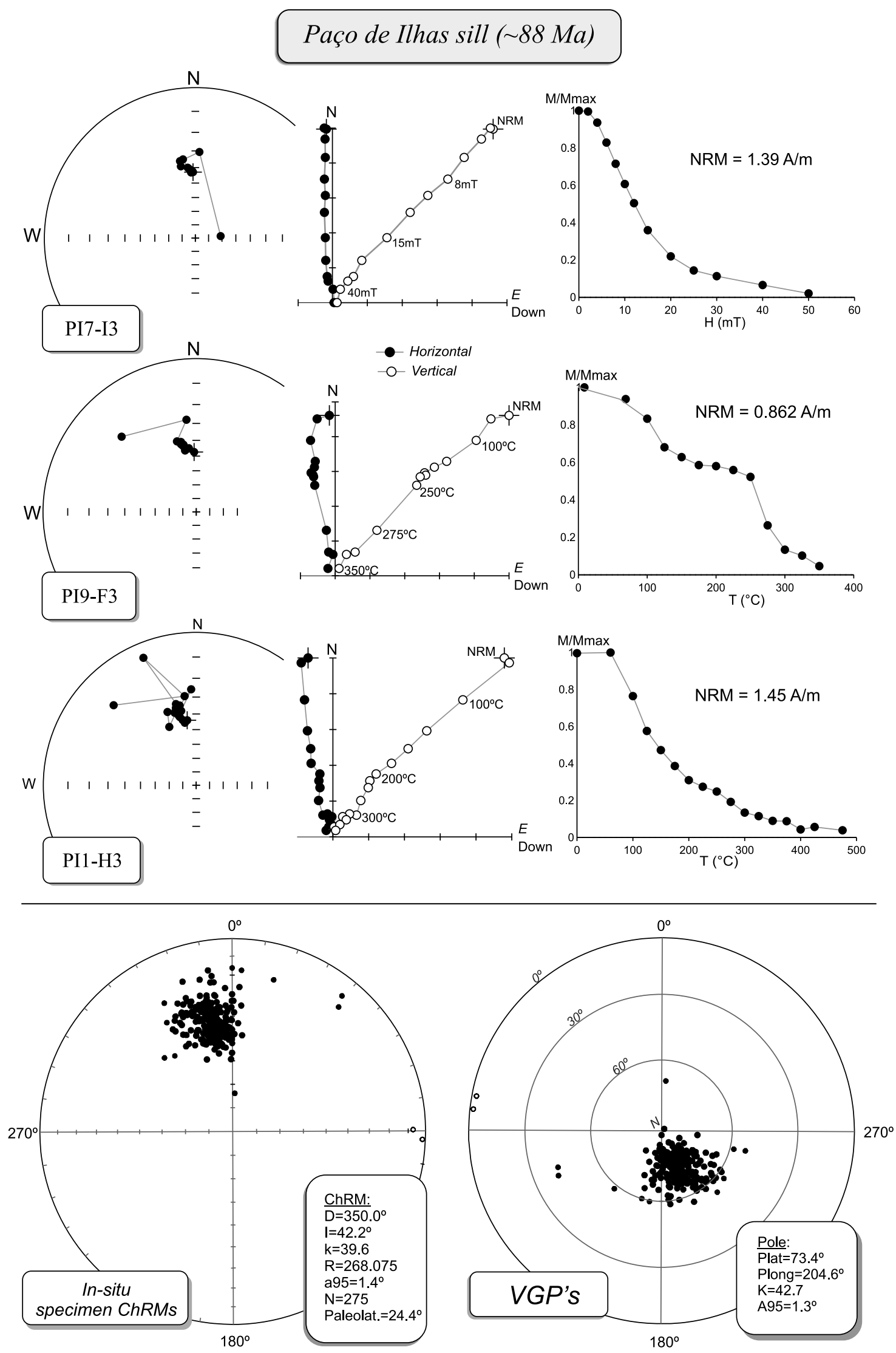

Figure 2. (top) Paleomagnetic results from the PI sill. Stereographic and orthogonal projections and remanence intensity versus AF demagnetizing field or demagnetizing temperature diagrams. (bottom) Characteristic Remanent Magnetization (ChRM) and corresponding Virtual Geomagnetic Poles (VGP's). 
Table 1. Paleomagnetic Results for PI and FF Sills: Mean Characteristic Remanent Magnetizations (ChRM) and Corresponding Paleomagnetic Poles ${ }^{\mathrm{a}}$

\begin{tabular}{|c|c|c|c|c|c|c|c|c|c|c|c|}
\hline & \multirow[b]{2}{*}{$\mathrm{N}$} & \multicolumn{5}{|c|}{ Mean ChRM } & \multicolumn{4}{|c|}{ Paleomagnetic Pole } & \multirow[b]{2}{*}{$\begin{array}{l}\text { Paleolatitude } \\
\text { (deg) }\end{array}$} \\
\hline & & Dec (deg) & Inc (deg) & $\mathrm{k}$ & $\mathrm{R}$ & a95 & $\begin{array}{c}\text { Pole } \\
\text { Longitude (deg) }\end{array}$ & $\begin{array}{c}\text { Pole } \\
\text { Latitude (deg) }\end{array}$ & A95 & $\mathrm{K}$ & \\
\hline $\begin{array}{l}\text { Paço d'Illhas (PI) } \\
\text { Foz da Fonte (FF) }\end{array}$ & 275 & 350.0 & 42.2 & 39.69 & 268.075 & 1.4 & 204.6 & 73.4 & 1.3 & 42.7 & 24.4 \\
\hline In-situ & 73 & 352.0 & 53.0 & 30.3 & 70.623 & 3.1 & 226.9 & 82.8 & 3.7 & 20.8 & 33.6 \\
\hline Tilt corrected & 73 & 346.5 & 44.3 & 30.3 & 70.623 & 3.1 & 217.1 & 73.8 & 3.3 & 26.0 & 26.0 \\
\hline
\end{tabular}

${ }^{\mathrm{a}}$ In the case of the FF sill, results before and after tilt correction are indicated. Dec: declination; Inc: inclination; k: precision parameter of ChRM; R: intensity of resultant vector; K: precision parameter of paleopole. See text for details.

components with a viscous magnetic overprint that was removed below $4-6 \mathrm{mT}$ or $100^{\circ} \mathrm{C}$. What emerged was a stable RM component that trends to the origin (Figure 2). After stepwise AF demagnetization until $30 \mathrm{mT}$, more than $90 \%$ of the NRM was removed, indicating that a low coercive phase is the principal magnetic carrier (Figure 2). Unblocking temperatures vary from $150^{\circ}$ to $500^{\circ} \mathrm{C}$ suggesting that this low coercive phase corresponds to titanomagnetite. The result is a positive (normal) and north directed RM with mean inclinations of $40-50^{\circ}$. A mean paleomagnetic pole was calculated using individual Virtual Geomagnetic Poles (VGPs) for each specimen (Figure 2; Table S1 in the auxiliary material). We chose this option because in the case of such a large intrusive layered-gabbroic complex ( $>3 \mathrm{~km}$ in length and more than $25 \mathrm{~m}$ in thickness), it is not possible to accurately identify different magmatic injection phases. No cut-off was applied to calculate the mean pole, because in that case we would be already assuming that the directional scatter reflects the PSV.

[13] The result of these analyses yields a mean ChRM of $\mathrm{D}=350.0^{\circ} ; \mathrm{I}=42.2^{\circ}\left(\mathrm{N}=275 ; \alpha_{95}=1.4^{\circ} ; \mathrm{k}=39.6\right)$, a mean paleomagnetic pole located at Long $=204.6^{\circ}$; Lat $=73.4^{\circ}$ $\left(\mathrm{A} 95=1.3^{\circ} ; \mathrm{K}=42.7\right)$, and a paleolatitude of $24.5^{\circ}$ (Figure 2 and Table 1) for this data set. We attempted to apply a baked contact test to the host sediments (Hauterivian) that surround the PI sill, but results were inconclusive due to the limited thickness of the sediments $(<2 \mathrm{~m}$; Figure 1d), which do not show typical hybrid and unbaked zones. Moreover, the high porosity of the Hauterivian sandstones may have facilitated fluid circulation and thermochemical magnetic overprinting during the emplacement of the sill.

\subsubsection{PI Rock Magnetism}

[14] In order to study the composition and origin of the magnetic carriers and the nature of the remanent magnetization recorded in PI rocks, we measured coercivity and grain-size dependent magnetic properties of characteristic samples. Specifically, Isothermal Remanent Magnetization (IRM) acquisition curves were obtained at fields up to $1.2 \mathrm{~T}$ for eight samples (Figure 3a). All samples reached saturation below $100 \mathrm{mT}$ indicating a low coercive phase as the dominant magnetic ferromagnetic mineral present in these samples. IRM data were analyzed assuming a cumulative logGauss function of the magnetizing field (CLG analysis) [Robertson and France, 1994], and then evaluated using the software developed by Kruiver et al. [2001] (Figure 3a). This method has been recently challenged by Heslop et al. [2004], who demonstrated that the influence of the starting state of the magnetic system, magnetic interaction and thermal relaxation can produce IRM curves that fail the log normal assumption [Robertson and France, 1994], and therefore can lead to misleading interpretations. However, these effects are minimized when using an AF demagnetized state and for materials that contain well-separated coercivity distributions. We thus acquired IRM curves from AF demagnetized $(100 \mathrm{mT})$ samples. In all cases, the curves showed a unimodal distribution of coercivity spectra (i.e., a single Gaussian curve), with saturation IRM (SIRM) values between 520 and $830 \mathrm{Am}^{-1}, \mathrm{~B}_{1 / 2}$ (the inducing field at which half of the SIRM is reached) between 30 and $45 \mathrm{mT}$, and dispersion parameter (DP, corresponding to one standard deviation of the logarithmic distribution) at $\sim 0.2 \mathrm{mT}$. SIRM and B1/2 values are in the typically low- to mediumcoercive range for minerals such as magnetite [Font et al., 2009, 2010; Gong et al., 2008b; Kruiver et al., 2001, $2003]$. DP values are similar $(0.20-0.25 \mathrm{mT})$ or all samples suggesting that magnetite grains in these samples have a homogenous grain-size distribution (Figure 3c).

[15] We compared the magnitude and demagnetization patterns of the NRM and SIRM [Fuller et al., 2002, 1988]. In rocks carrying a Thermal Remanent Magnetization (TRM) the NRM:IRM ratio is about $10^{-2}$, whereas smaller values generally imply a secondary magnetization. All samples exhibit roughly straight-line behavior between $10^{-2}$ and $10^{-3}$, indicating a primary TRM origin for the magnetization (Figure 4a). The absence of typical concave-upward curves observed in remagnetized rocks, generally reflecting bimodal associations of soft and hard (secondary) fractions, further supports a primary TRM origin.

[16] Thermomagnetic analyses at high (HT) and low (LT) temperatures under Argon-controlled and ambient atmosphere, respectively, were done on four samples from which two representative examples are illustrated in Figure 5a. No major transitions are observed during LT analyses, while heating exhibited unblocking temperatures between 500 and $560^{\circ} \mathrm{C}$ (Figure 5a), typical of titanomagnetite. In some samples (i.e., PI1_K; Figure 5a), a typical Hopkinson peak near the Curie temperature indicates admixture of fine (SD to PSD) magnetic particles [Dunlop and Ozdemir, 1997]. During cooling below $700^{\circ} \mathrm{C}$, HT curves are irreversible, indicating that authigenic magnetic minerals (probably magnetite) were created during the heating process. Consequently, AF demagnetization is more suitable than thermal demagnetization for these rocks.

[17] Thermal demagnetization of tri-axial orthogonal IRM [Lowrie, 1990] was performed for eight representative 

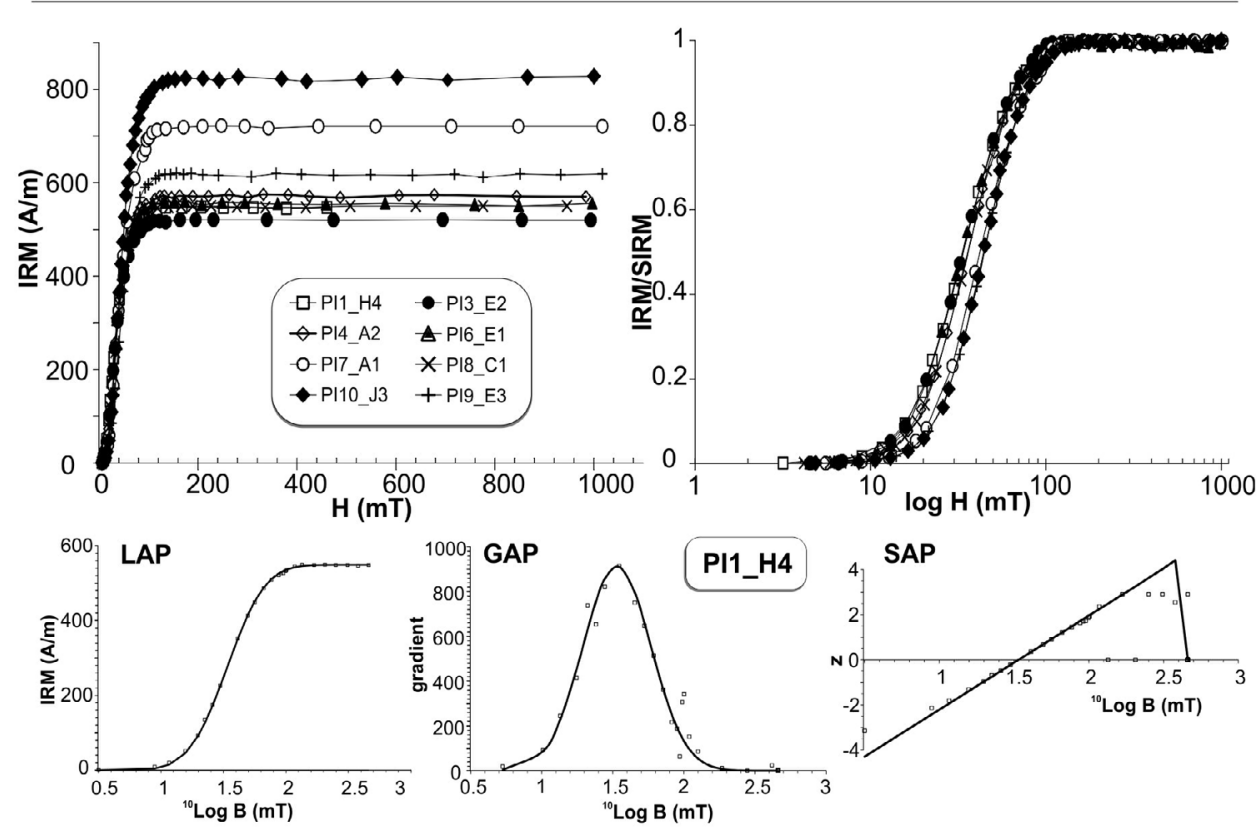

\section{B) Foz da Fonte (FF)}
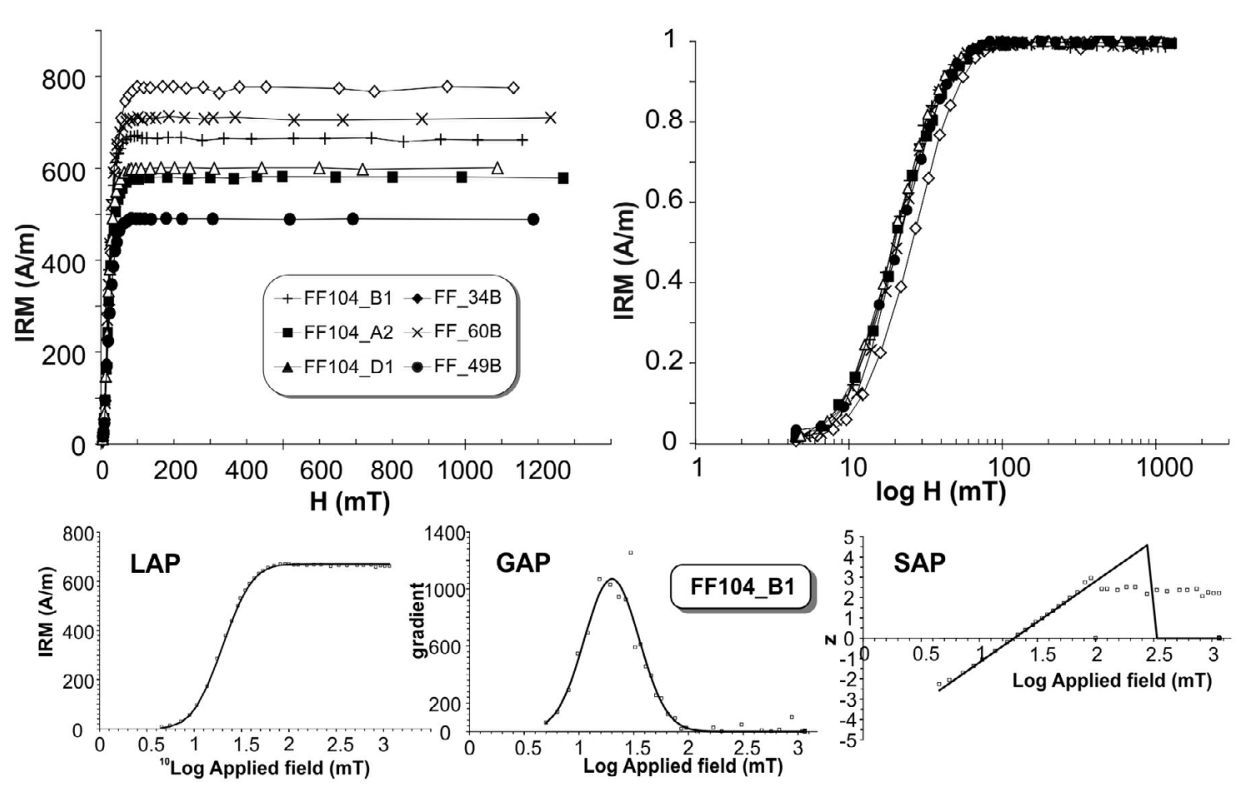

Figure 3. Isothermal Remanent Magnetization (IRM) acquisition of (a) PI and (b) FF samples. Normalized (IRM/SIRM) data are represented in horizontal logarithmic scale to enhance differences in the coercivity spectra. (c) Examples of IRM data treated by cumulative log-Gaussian analysis [Kruiver et al., 2001; Robertson and France, 1994]. LAP: Linear Acquisition Plot; GAP: Gradient Acquisition Plot, respectively; B1/2: induced field corresponding to half SIRM.

samples and showed predominance of the softer magnetic fraction, whereas medium to hard fractions were weak (Figure $5 \mathrm{~b}$ ). In the soft fraction, more than $90 \%$ of the imparted remanence is demagnetized during heating to $200^{\circ} \mathrm{C}$, after which the RM decreases progressively until $520^{\circ} \mathrm{C}$. Together with IRM and thermomagnetic analyses, these results indicate that titanomagnetite, with variable Ti-content, is the principal magnetic carrier in these rocks. FORC and analyses of hysteresis parameters were conducted for five samples. FORC diagrams show a clear contribution of two populations: a SD-like population with closed inner contours, and a second MD-like population with diverging outer contours (Figure 6, top). Once titanomagnetite was identified as the main magnetic carrier, hysteresis ratios Mrs/Ms versus $\mathrm{Hcr} / \mathrm{Hc}$ were plotted using a modified Day plot like those used by Dunlop [2002a]. Figure 6 (bottom) illustrates the 

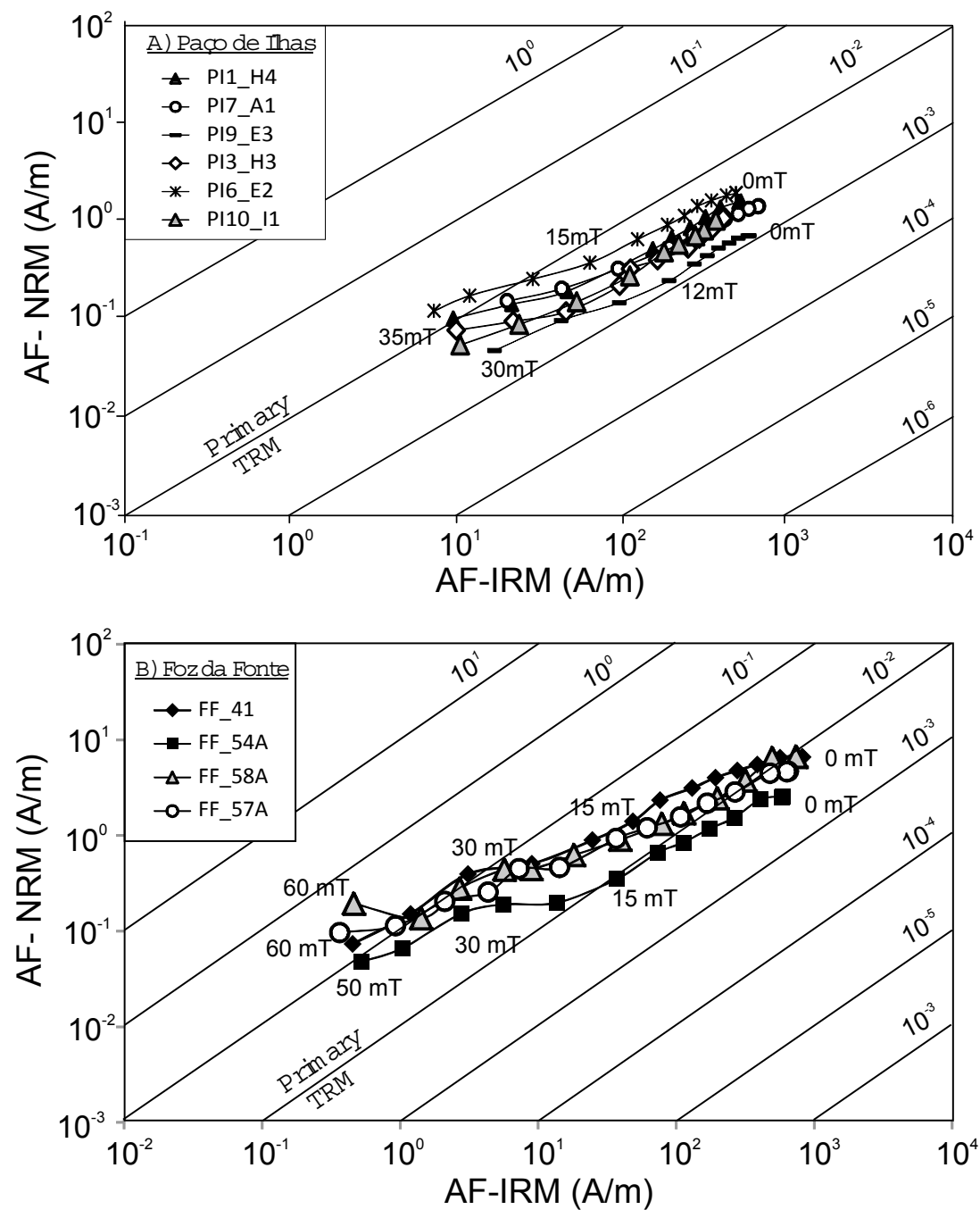

Figure 4. AF-IRM versus AF-NRM diagram [Fuller et al., 2002] from (a) PI and (b) FF samples. All samples show linear demagnetization patterns and AF-NRM:AF-IRM ratios near typical values for unremagnetized igneous rocks $\left(\sim 10^{-2}\right)$.

theoretical SD+MD mixing curves for grains of magnetite (TM0 and TM60) [Dunlop, 2002a] and experimental data from intrusive rocks (gabbro and dolerite) [Dunlop, 2002b]. The hysteresis ratios of PI samples are similar to those of gabbros that carry a primary magnetization.

\subsubsection{PI SEM and Optical Microscopic Analyses}

[18] The nature and origin of the ferromagnetic minerals in the PI sill were investigated on four samples using an SEM and these data are illustrated in Figure 7. Chemical composition was obtained by EDS analysis. In all samples, iron oxides are ubiquitous and easily identified by the characteristic iron peaks at 6.40 and $7.06 \mathrm{keV}$ (Figure 7a). Crystals exhibited well preserved and euhedral shapes, with grainsizes varying from 50 to $100 \mu \mathrm{m}$ (Figures $7 \mathrm{~b}$ and $7 \mathrm{c}$ ). Spinel-like and cubic morphologies, together with Ti in EDS spectra indicate that titanomagnetite as the principal magnetic carrier. Titanomagnetite grains occasionally show exsolved ilmenite lamellae, indicative of deuteric high temperature oxidation (i.e., during cooling). Dissociation between $\mathrm{Ti}$ and $\mathrm{Fe}$ is well illustrated by SEM Mapping (Figure 7d). Thin section analyses by optical ore microscopy have confirmed the presence of such simple two-phase assemblages, corresponding to oxidation stage $\mathrm{C} 3-\mathrm{C} 4$ of Haggerty [1991] (Figure 7e). However, most of the ilmenite lamellae show an advanced stage of high temperature oxidation similar to the one described by Hoffman et al. [2008]. Moreover, the large euhedral ilmenite crystals present also show the same stage of oxidation (Figure 7f). As interpreted by Hoffman et al. [2008], we also believe that these altered ilmenites host a SD population of titanohematite that disassociates above $500^{\circ} \mathrm{C}$ when heated in the $\mathrm{KT}$ experiment, producing an almost pure fine-grained magnetite. However, 


\section{Paço de Ilhas (PI)}
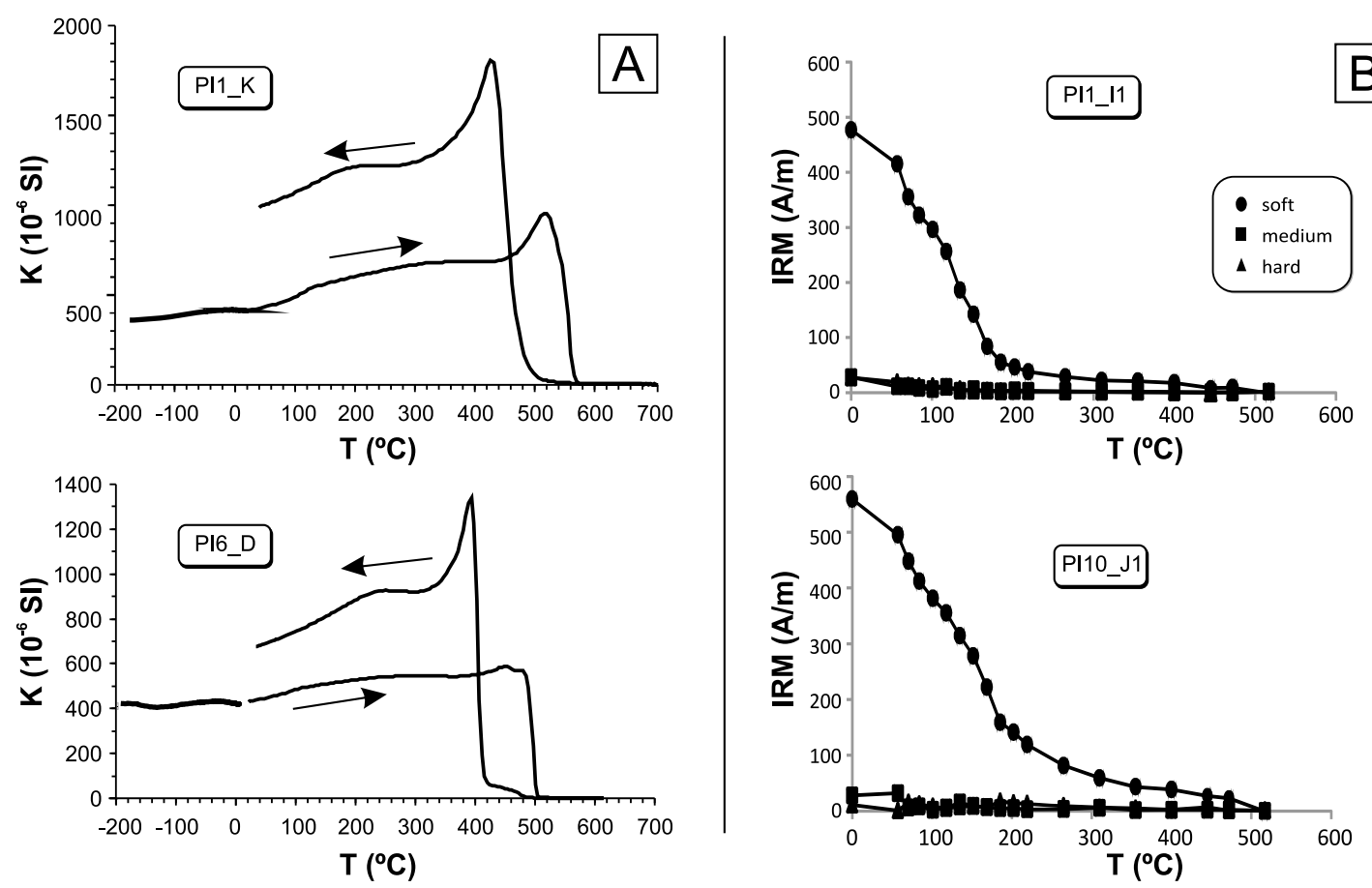

\section{Foz da Fonte (FF)}
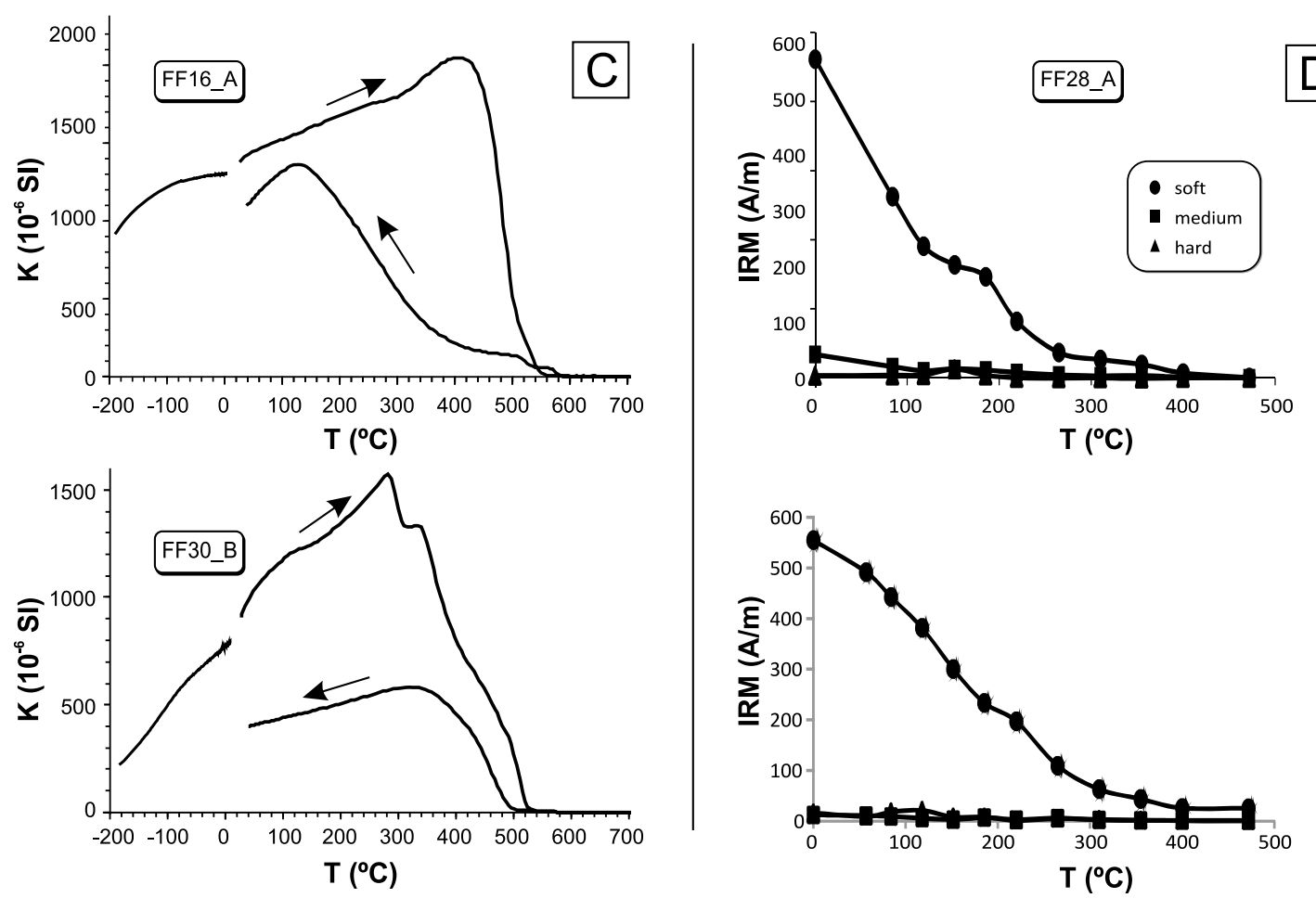

Figure 5. (a) Thermomagnetic susceptibility curves at low and high temperatures in an Argon controlled atmosphere for PI samples. (b) Thermal demagnetization of triaxial orthogonal IRM's [Lowrie, 1990] for PI samples. (c) Thermomagnetic curves in Ar-controlled atmosphere for FF samples. (d) Thermal demagnetization of triaxial orthogonal IRM's [Lowrie, 1990] for FF samples. 

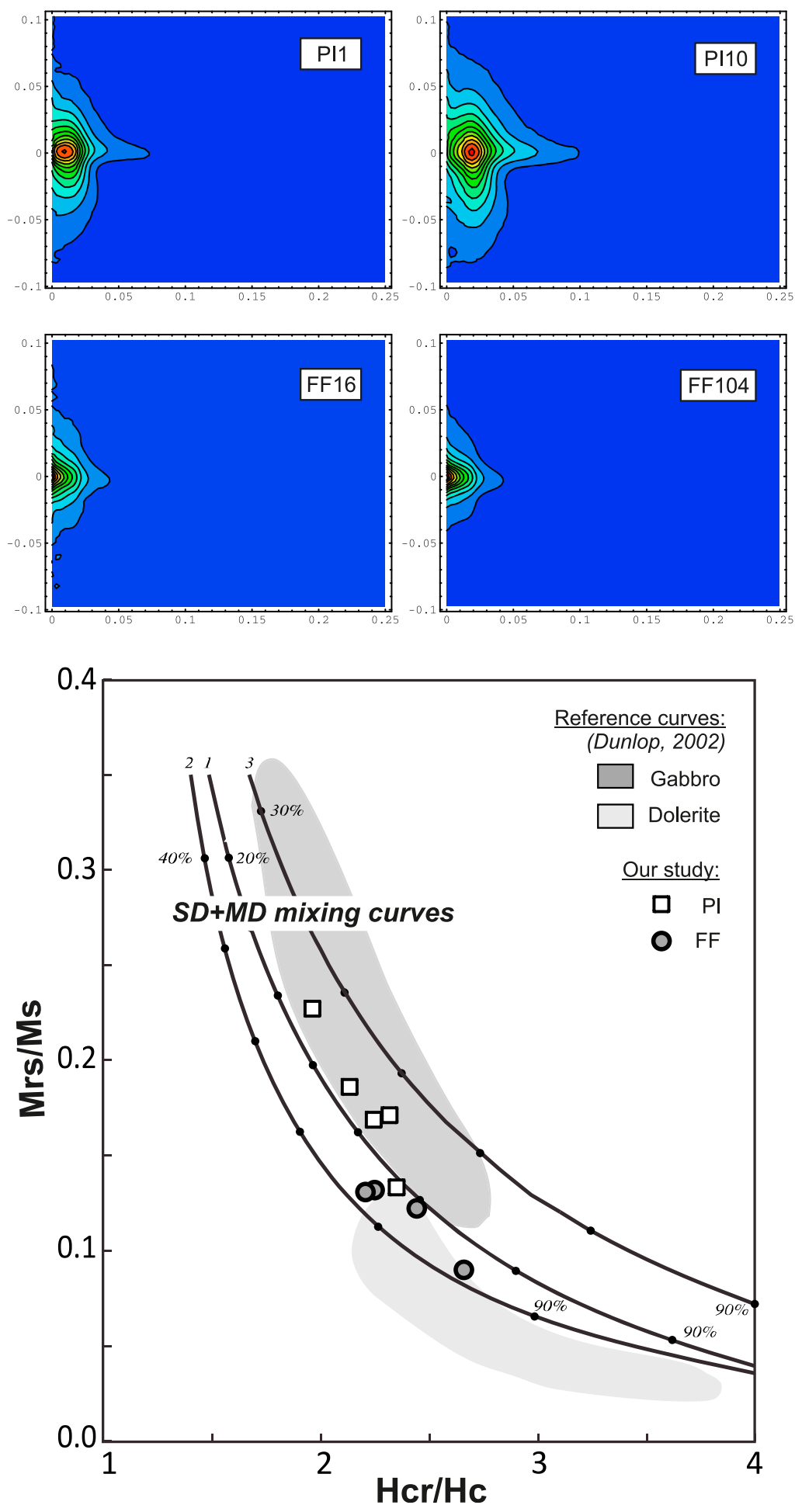

Figure 6. (top) FORC diagrams for PI and FF samples. (bottom) Modified Day plot showing hysteresis data from PI and FF samples compared to referenced data of gabbro and dolerite from Dunlop [2002b].

this interpretation is not fully supported by the FORC diagrams (Figure 6, top); the peak of the FORC distribution occurs at a coercivity that seems too low (around $20 \mathrm{mT}$ ) for SD titanohematite. At present, we do not have a clear explanation to account for this discrepancy.
[19] To summarize, microscopic observations point to a well-preserved primary magnetic mineralogy, contemporaneous with the cooling time of the sill. This corroborates the magnetic analyses indicating a primary origin for the remanent magnetization exhibited by these rocks. 

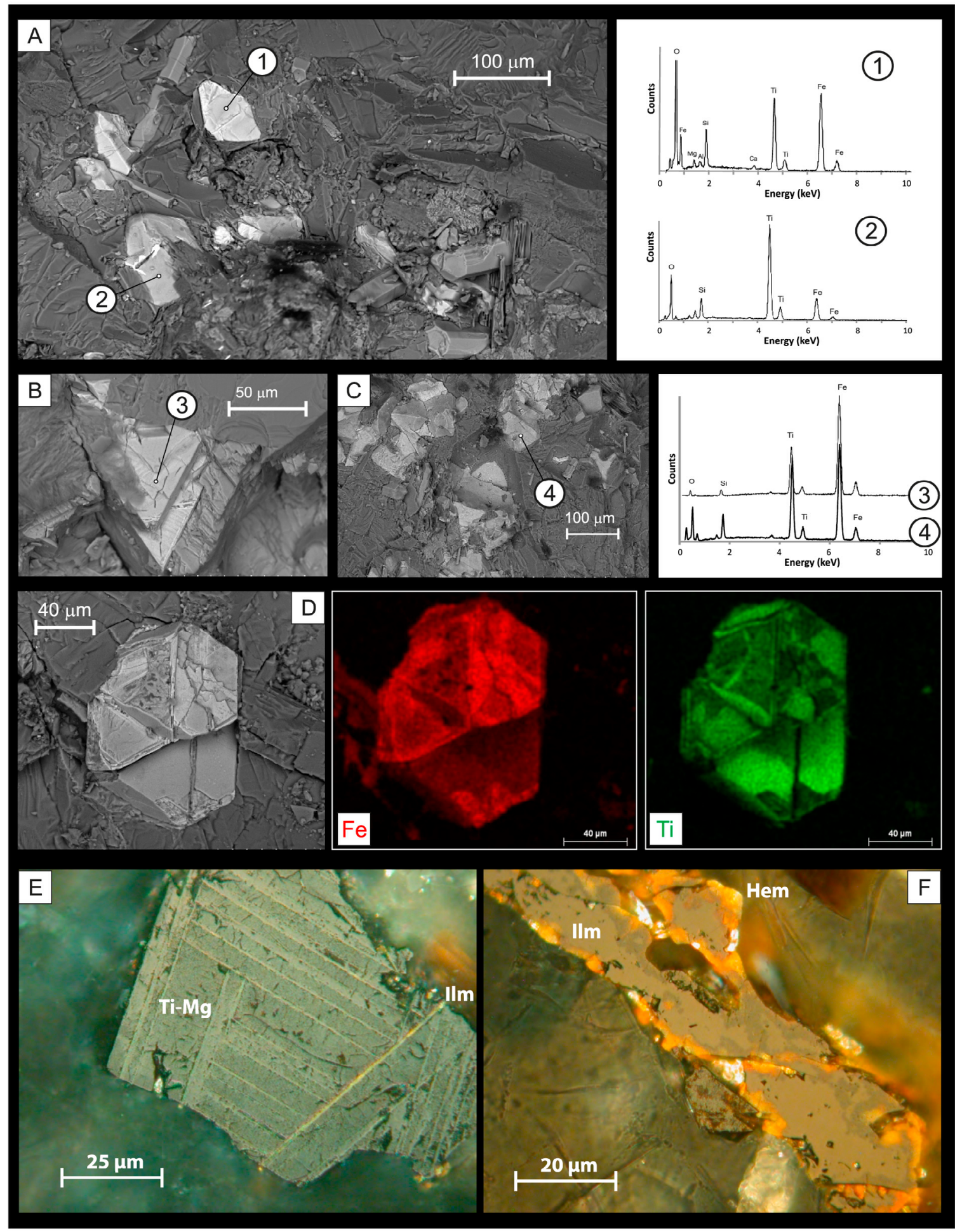

Figure 7. (a-d) Scanning Electron Microscopy (SEM) images coupled to Energy Dispersive Spectra (EDS) analyses of PI samples. Ti-Fe oxides are ubiquitous in the form of well-preserved crystals with spinel-like and cubic morphologies (see text for details). (e-f) Reflected light photo micrographs of sample PI1-A2 (Figure 7e): Oil immersion, crossed nicols. Titanomagnetite with exsolved thin ilmenite lamellae (oxidation stages $\mathrm{C} 3-\mathrm{C} 4$ ). The ilmenite lamellae appear to be inhomogeneous with internal granulation and sample PI6-F1 (Figure 7f): Oil immersion, crossed nicols. Subhedral ilmenite grain partially oxidized. The red internal reflections are characteristic of hematite. 

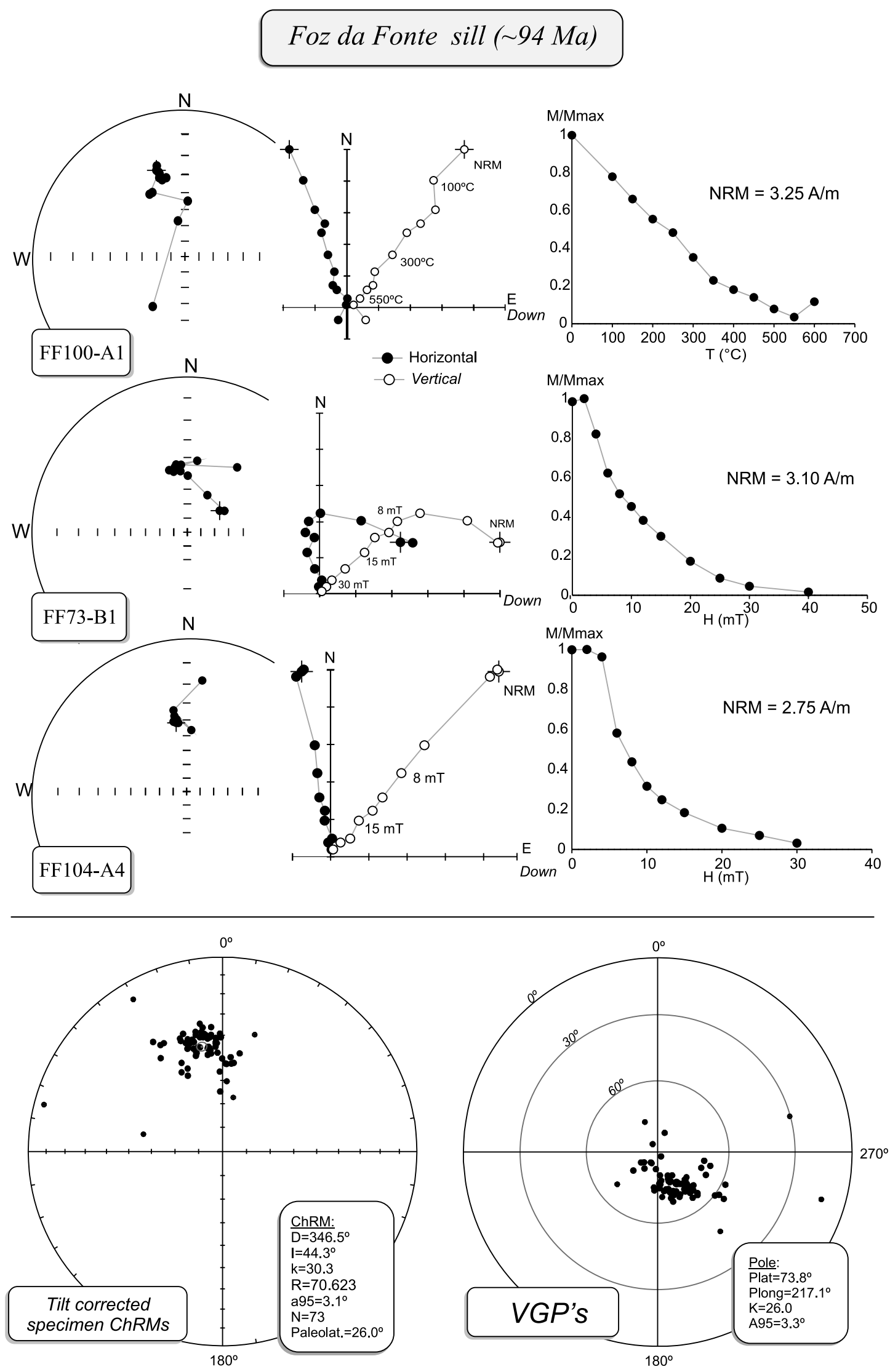

Figure 8. (top) Paleomagnetic results from FF sill. Stereographic and orthogonal projections and remanence intensity versus AF demagnetizing field or demagnetizing temperature diagrams. (bottom) ChRM after tilt correction $\left(\mathrm{D}=230, \mathrm{I}=10^{\circ}\right)$ and corresponding VGP's. 


\subsection{Foz da Fonte (FF)}

\subsubsection{FF Paleomagnetism}

[20] A total of 86 specimens were demagnetized using AF (72) and thermal (14) treatment. Of these, 73 samples yield stable demagnetization patterns at high fields and/or high temperatures (Table S2 in the auxiliary material). Zijderveld diagrams show two magnetic components with a viscous magnetic overprint removed below $4-6 \mathrm{mT}$ and $150^{\circ} \mathrm{C}$, and a high-field/temperature remanence projected to the origin (Figure 8). After stepwise AF demagnetization to $15-30 \mathrm{mT}$, more than $90 \%$ of the NRM was removed, indicating low coercive minerals as the principal magnetic carriers (Figure 8). Unblocking temperatures around $550^{\circ} \mathrm{C}$ suggest that this low coercive phase corresponds to titanomagnetite with a low Ti-content (Figure 8). In situ magnetic orientations are positive (normal) and north directed, with mean inclinations of $45-55^{\circ}$.

[21] A structural orientation for this unit of $230^{\circ} / 10^{\circ}$ (strike/dip) was measured for field exposures and this was used as a tilt correction to correct the specimen-based mean ChRM (Figure 8). As was the case for PI samples, we calculated the mean ChRM and individual VGP using specimen-based mean directions. The coordinates of the mean $\mathrm{ChRM}$ are $\mathrm{D}=346.5^{\circ} ; \mathrm{I}=44.3^{\circ}\left(\mathrm{N}=73, \alpha 95=3.1^{\circ}\right.$; $\mathrm{k}=30.3$ ). The mean paleomagnetic pole calculated from all VGPs is located at Long $=217.1^{\circ}$; Lat $=73.8^{\circ}\left(\mathrm{A} 95=3.3^{\circ}\right.$; $\mathrm{K}=26$ ). Paleolatitude is $26.0^{\circ}$ (Figure 8 and Table 1). We attempted to apply a baked contact test to the host sediments above FF sill. However, results were inconclusive because the age determined for these sediments is too close to the age of the sill.

\subsubsection{FF Rock Magnetism}

[22] IRM acquisition curves obtained from six samples are s-shaped, typical of SD-PSD grain sizes, and show a single, low-coercive phase with $90 \%$ of saturation reached at $100 \mathrm{mT}$ (Figure 3b). All curves fit into a unimodal distribution of coercivity spectra, with SIRM values between 400 and $800 \mathrm{Am}^{-1}, \mathrm{~B}_{1 / 2}$ between 20 and $30 \mathrm{mT}$, and DP around 0.2 to $0.3 \mathrm{mT}$. These results are indicative of a single low- to medium-coercive phase, with uniform grain-size distribution. The similarity to results obtained for PI samples indicates a similar magnetic mineralogy for both sills (Figure 3). Once plotted on a Fuller et al. [2002] diagram, NRM-IRM ratios lie between the $10^{-1}$ and $10^{-2}$ thresholds, characteristic of rocks carrying a primary TRM origin for the remanence (Figure 4b). The roughly linear shape of the curves indicates that no magnetically hard material is present.

[23] No major transitions are observed at LT, while during HT analysis, unblocking temperatures fall between 520 and $560^{\circ} \mathrm{C}$ (Figure 5c). Sample FF_16A exhibits Curie temperatures at $500-550^{\circ} \mathrm{C}$ and a Hopkinson peak that indicates mixture of fine magnetic particles (SD to PSD) [Dunlop and Ozdemir, 1997]. Sample FF_30B shows a more complex mineralogy, with Curie temperatures at $\sim 300^{\circ}, 400^{\circ}$ and $520^{\circ} \mathrm{C}$ (Figure $5 \mathrm{c}$ ). These results indicate the presence of SD to $\mathrm{MD}$ titanomagnetite with different Ti-content. During cooling below $700^{\circ} \mathrm{C}$, curves are irreversible indicating that authigenic magnetic minerals (probably magnetite) were generated during the heating process.

[24] After thermal demagnetization of tri-axial orthogonal IRM, all samples show predominance of the softer magnetic fraction, whereas medium to hard fractions are undetectable (Figure 5d). In the soft fraction, more than $90 \%$ of the induced remanence is demagnetized by $\sim 300^{\circ} \mathrm{C}$. In sample FF 28A, three phases of $\mathrm{Tb} \sim 120^{\circ} \mathrm{C}$ and $\sim 250^{\circ} \mathrm{C}$ and $\sim \overline{40} 0^{\circ} \mathrm{C}$ are identified. For sample $\mathrm{FF} 14 \mathrm{~B}$, only a $\mathrm{Tb}$ $\sim 300^{\circ} \mathrm{C}$ is clearly identified. As was the case for PI, these results confirm that titanomagnetite, with variable Ti-content is the principal magnetic carrier.

[25] The magnetic domain state was checked using FORC measurements, which produced characteristic MD contours, all diverging from the origin (Figure 6, top). Figure 6 (bottom) shows that hysteresis ratios for FF samples lie close to the region expected for unremagnetized dolerites [Dunlop, 2002b], although, our data better fit the theoretical mixing curves and show a tendency toward a finer grain size than shown by Dunlop [2002a].

\subsubsection{FF SEM and Optical Microscopic Analyses}

[26] SEM photographs show the presence of numerous iron oxides identified by the association of $\mathrm{O}$, Ti and $\mathrm{Fe}$ elements in the EDS spectra (Figures 9a-9e). Spinel-like and cubic morphologies, as well as the systematic association of Ti in EDS, indicate titanomagnetite as the principal magnetic carrier. These crystals exhibit well preserved euhedral shapes, with grain-sizes lying between 20 and $100 \mu \mathrm{m}$ (Figures 9a-9e).

[27] Thin section analyses by optical ore microscopy have confirmed the presence of subhedral grains of titanomagnetite, with oxy-exsolved ilmenite lamellae corresponding to oxidation stage C3 of Haggerty [1991]. Our work also yielded evidence for more advanced stages of oxidation (C6), as illustrated in Figure 9f. In contrast to PI samples, in FF samples ilmenite lamellae and crystals are well preserved. We also noted the sparsity of iron sulfides (three to four grains at thin section scale). Although not identifiable without further analyses, these are certainly non-magnetic as suggested by the results obtained in the Lowrie test. In addition, small veins of Ti-maghemite grains are present along the cracks of very few grains of Ti-magnetite, and may account for the irreversibility in the KT curves.

[28] In summary, microscopic observations indicate that the FF sill preserves a primary magnetic mineralogy. This was acquired during cooling and supports a primary origin for the remanent magnetization.

\section{Discussion}

\subsection{New Paleomagnetic Poles for Iberia at 88 and 94 Ma}

[29] The present paleomagnetic and rock magnetic study of the PI and FF sills provides two new important Cretaceous paleomagnetic poles for the Iberian Plate, at $88 \mathrm{Ma}$ and $94 \mathrm{Ma}$, respectively. Stable demagnetization patterns, the presence of titanomagnetite as principal magnetic carriers, as well as absence of secondary oxides, indicate a primary (i.e., during cooling) origin for the isolated remanence. The corresponding paleopoles are classified by a $\mathrm{Q}$ factor [van der Voo, 1990] of 5. However, as the ages of the PI and FF sills fall within the quiet zone of the CNPS, we have replaced the normally used reversal criteria with our very detailed magnetic mineralogical study, thus yielding a $\mathrm{Q}$ value of 6 for both poles. 


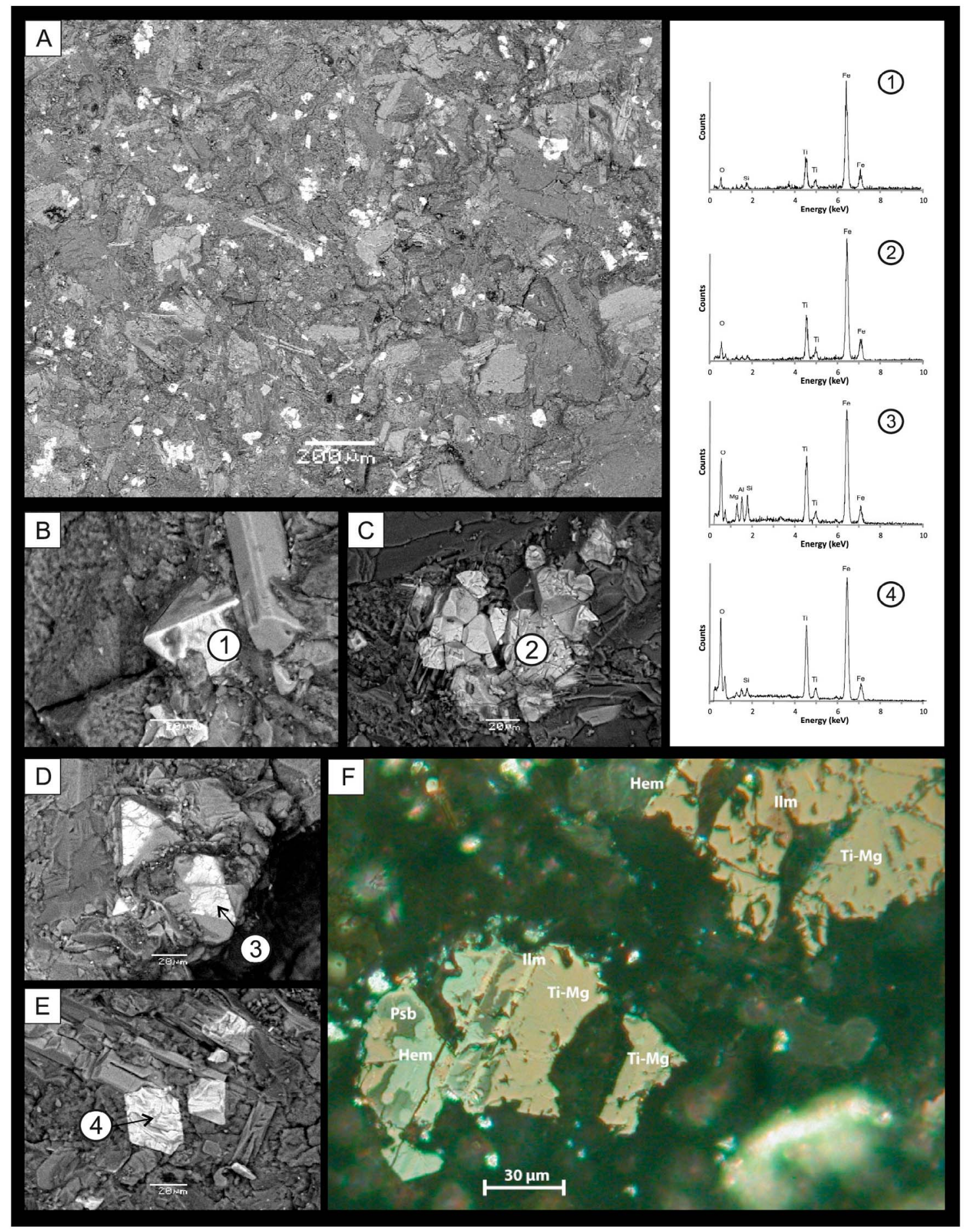

Figure 9. (a-e) SEM images coupled to EDS analyses of FF samples. Ti-Fe oxides are ubiquitous, in the form of well-preserved crystals with spinel-like and cubic morphologies (see text for details). (f) Reflected light photomicrograph (oil immersion) of a polished thin section from sample FF16-A2 showing different stages of high temperature oxidation. On the upper right part of the photo, a large homogeneous grain of Ti-magnetite with an anhedral ilmenite inclusion. On the lower left part of the photo, a single crystal showing, to the right, ilmenite intergrowths in titanomagnetite (oxidation stage $\mathrm{C} 4$ ) and to the left, areas of exsolved pseudobrookite, titanohematite and residual ilmenite (oxidation stage C6). 
[30] Because thin magmatic bodies, particularly extrusive rocks such as basalts, have relatively short cooling times when compared to secular variation cycles $(\sim 10 \mathrm{kyr}[$ Merrill and McFadden, 2003]), they can record a snapshot of the geomagnetic field. Therefore, we have attempted to evaluate the contribution of the PI and FF sills to the paleosecular variation during the CNPS. The most common and traditional method to study the PSV of the geomagnetic field is based on the analysis of the dispersion of VGPs determined from volcanic sites for a given latitude and age [Cox, 1970; Irving and Ward, 1964]. During the last 40 years, many PSV models have been proposed, among which the Model G [McFadden et al., 1988] and the TK03.GAD models [Tauxe and Kent, 2004] are the most recent and widely used (see Deenen et al. [2011] for a review). However, Linder and Gilder [2012] recently showed that the traditionally assumed latitudinal dependence of the VGP dispersion parameters (i.e., $S(\lambda)$ parameter) is a mathematical artifact resulting from the conversion from directions to poles. These new findings strongly question the validity of the methods used until now to estimate the PSV. An alternative method would be to use here directional distributions instead of VGP distributions. However, because most of PSV models are based on VGP distribution and not on directional distribution, there is no available database to use for comparison. In conclusion, the contribution of PSV in our data is difficult to evaluate but several hypothesis can be proposed. The first one is to consider that, despite their large and complex structure, the dense cluster of magnetic directions of the PI and FF sills indicate a record of a snapshot of the geomagnetic field. However, the fact that both corresponding poles well fit the global APWP at around $80 \mathrm{Ma}$ and $100 \mathrm{Ma}$ (Figure 10) rather argue against such hypothesis. The second scenario is to consider that PSV was averaged out within individual samples. Actually, the PI sill corresponds to a large and thick intrusive layered-gabbroic complex with porphyritic textures, different lithology and presence of magmatic joins and syenites (Figure 1) [Mahmoudi, 1991; Miranda, 2010]. This rather suggests a much longer cooling time than in the case of lava flows for example. Therefore we suggest that the dense clustering of magnetic directions could be partially or totally justified by the fact that each paleomagnetic sample has minimized PSV through a sufficiently long cooling time. This is plausible when variable Ti-content in titanomagnetite (i.e., variable unblocking temperatures and consequently lock-in time magnetization) and grain size (SD to MD) are observed in the rocks, as observed in the PI and FF sill. Moreover, this effect can also be amplified by the fact that PSV was lower during the quiet zone of the Cretaceous than for the last $5 \mathrm{Myr}$ [Biggin et al., 2008]. These results may suggest that intrusive gabbroic rocks are excellent candidates to obtain reliable paleomagnetic pole in which the PSV has been minimized.

\subsection{APWP of Iberia During the Cenozoic}

[31] Since the end of the 1950s, the motion of the Iberian Plate relative to Europe and Africa was extensively investigated, but is still a matter of debate. Carey [1958] was the first to propose, on the basis of geological data, a counterclockwise rotation of $30^{\circ}$ to $40^{\circ}$ linked to the opening of the Bay of Biscay during the Cretaceous. Bullard et al. [1965] further confirmed Carey's [1958] hypothesis from numerical paleogeographic modeling. Using analyses of seafloor magnetic anomalies from the Bay of Biscay, Scotese et al. [1988] suggested a counterclockwise rotation of $30^{\circ}$ between 92 and $84 \mathrm{Ma}$, and $5^{\circ}$ between 84 and $66 \mathrm{Ma}$, whereas Srivastava et al. [1990a] argued for a linear counterclockwise rotation of $30^{\circ}$ between 125 and 83 Ma. However, in the broad transitional zone at magma-poor rifted margins, the seafloor-spreading origin of magnetic anomalies is still a matter of debate [Bronner et al., 2011; Sibuet et al., 2007; Tucholke et al., 2007]. Moreover, due to the presence of the CNPS, kinematic models based on seafloor magnetic anomalies are limited and paleomagnetic methods are then preferred.

[32] Van der Voo [1969] was the first to provide paleomagnetic evidence for the counterclockwise rotation of Iberia of $35^{\circ}$ since the Jurassic. Later paleomagnetic investigations of marine sediments from the Algarve and Lusitanian Basins by Galdeano et al. [1989] suggested a twophase evolution with a relatively rapid phase of rotation of $26^{\circ}$ during the Barremian Stage (125-110 Ma), and a slower phase of $13^{\circ}$ from the Albian to Maastrichtian (110-83 Ma). Moreau et al. [1997] proposed a counterclockwise rotation of $22^{\circ} \pm 14^{\circ}$ between 132 and $124 \mathrm{Ma}$. On the other hand, Storetvedt et al. [1987, 1990] suggests a more complex evolution involving clockwise and counterclockwise rotations before the coupling of Iberia to Europe. More recently, Gong et al. [2008a] suggested a single event of rotation, limited to the Aptian, based on new paleomagnetic data from the Organyà Basin, Spanish Pyrenees. It is important to note here that most of these interpretations have the severe limitation of being based on a low resolution and low quality paleomagnetic database. Their main problems are the paucity of precise radiometric dates, low age resolution of sampling, a small number of sites and samples, the absence of field tests and unknown paleo-horizontal corrections in the case of igneous rocks, and poorly defined inclination corrections for sedimentary rocks. Except for the Late Cretaceous, most of the Cretaceous paleomagnetic poles for the Iberian Plate were developed from sedimentary rocks (Table 2) that are known to be prone to remagnetization [e.g., Dinarès-Turell and Garcia-Senz, 2000; Font et al., 2006; Gong et al., 2009, 2008b; Jackson et al., 1992, 1993; McCabe and Elmore, 1989], and for which the magnetic inclination may be biased by depositional and post-depositional physical mechanisms [e.g., Tauxe and Kent, 2004]. Consequently, a re-examination of the paleomagnetic database for Iberia, as well as the acquisition of new paleomagnetic poles, preferentially from igneous rocks, is necessary.

[33] Available Cretaceous paleomagnetic poles for Iberia between 158 and $68 \mathrm{Ma}$ are shown in Figure 10a and listed in Table 2. From the 30 paleomagnetic poles available for this period of time, 20 were selected for the calculation of mean paleopoles. Those paleopoles that were not used in the analysis are those obtained from the Salema intrusion (number 1 in Table 2 [Storetvedt et al., 1990]) and the Lisbon Volcanic Complex (LVC; number 2; [van der Voo and Zijderveld, 1971]), which, despite their stable isolated magnetic remanence directions, show discrepancies relative to their age (Figure 10a). The LVC passed a fold test [van der Voo and Zijderveld, 1971] and was dated at $72.6 \pm 3.5 \mathrm{Ma}$ (K-Ar on five whole-rock samples) [Ferreira and Macedo, 1979]. However, the position of the pole plots closer to the 

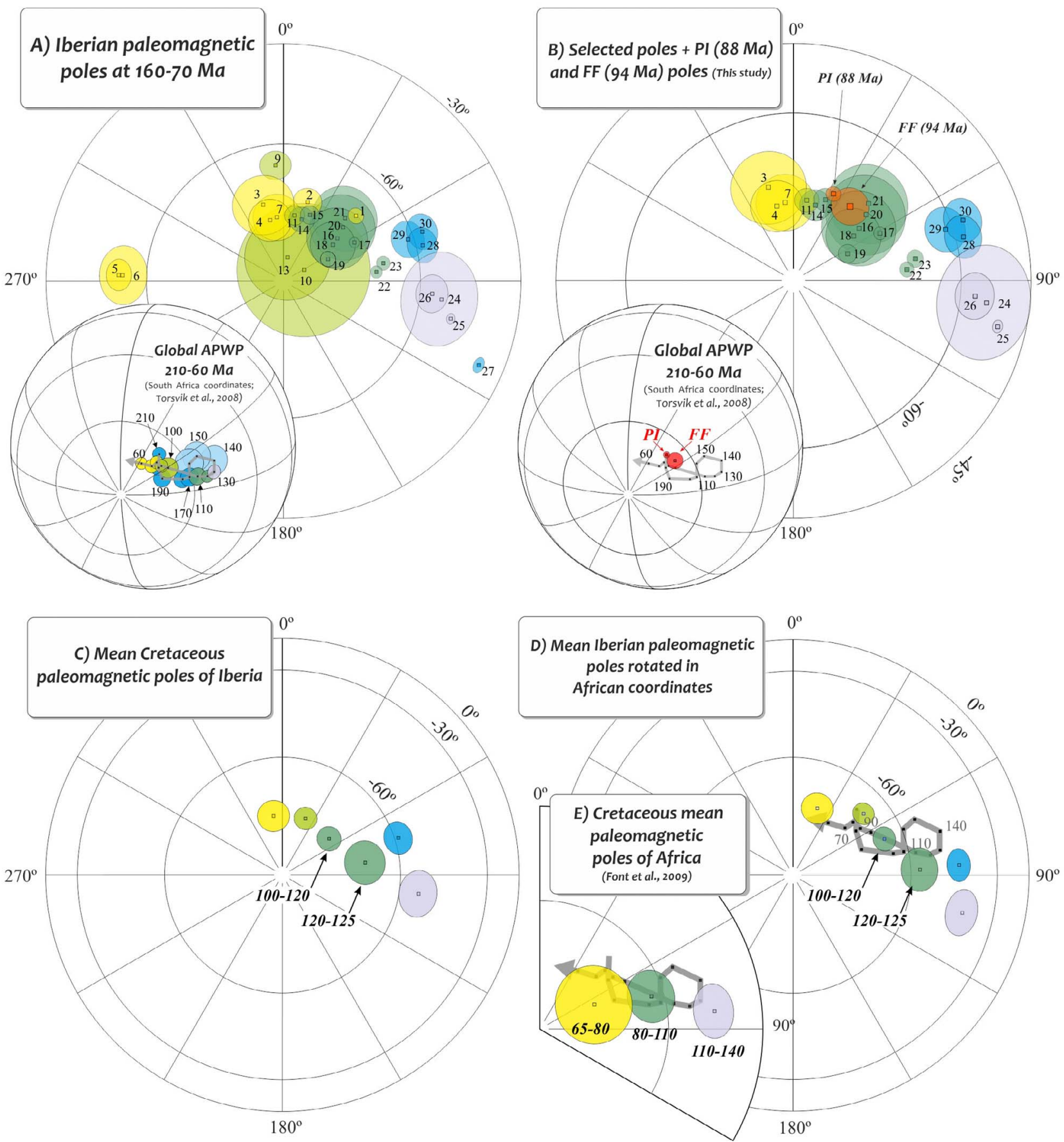

\section{$70-88 \mathrm{Ma}$}

$88-100 \mathrm{Ma}$

$100-125 \mathrm{Ma}$

$125-136 \mathrm{Ma}$

136-160 Ma

Figure 10. (a) Cretaceous paleomagnetic poles for Iberia (Table 1). (b) Selected paleomagnetic database and PI and FF (this study) poles (their position in African coordinates on the global APWP from Torsvik et al. [2008] is also shown). (c) Mean Cretaceous paleomagnetic poles for Iberia calculated from our paleomagnetic database (Table 1). (d) Mean Cretaceous paleomagnetic poles rotated into African coordinates compared to the global APWP. (e) Comparison with mean Cretaceous poles from Africa (compilation from Font et al. [2009]). All representations are in the southern hemisphere. 
Table 2. Selected paleomagnetic poles of Iberia during Cretaceous and Late Jurassic ${ }^{\mathrm{a}}$

\begin{tabular}{|c|c|c|c|c|c|c|c|c|c|}
\hline \multirow[b]{2}{*}{ Number } & \multirow[b]{2}{*}{ Formation } & \multirow[b]{2}{*}{ Lo/hi-Age } & \multirow[b]{2}{*}{$\begin{array}{l}\text { Age } \\
\text { (Ma) }\end{array}$} & \multicolumn{2}{|c|}{ Directions } & \multicolumn{3}{|c|}{ Paleomagnetic Poles } & \multirow[b]{2}{*}{ Reference } \\
\hline & & & & $\begin{array}{c}\mathrm{D} \\
(\mathrm{deg})\end{array}$ & $\begin{array}{c}\mathrm{I} \\
(\mathrm{deg})\end{array}$ & $\begin{array}{c}\text { Latitude } \\
\text { (deg) }\end{array}$ & $\begin{array}{l}\text { Longitude } \\
\text { (deg) }\end{array}$ & a95 & \\
\hline 1 & Monchique - Salema intrusion $^{\mathrm{a}}$ & 72 & 68 & 341 & 42 & -69.2 & 48.1 & 1.7 & Storetvedt et al. [1990] \\
\hline 2 & Lisbon Volcanic Complex ${ }^{\mathrm{a}}$ & $70-74$ & 72 & 352 & 40 & -72.5 & 17.0 & 3 & van der Voo and Zijderveld [1971] \\
\hline 3 & Monchique massif - syenites & $70-74$ & 72 & 181 & -42 & -76.9 & 357.5 & 4,5 & Storetvedt et al. [1990] \\
\hline 4 & Monchique Syenite & $70-74$ & 72 & 182 & -37 & -73.3 & 345.0 & 6.5 & van der Voo [1969] \\
\hline 5 & Sines (Syenite, diabase, diorite) ${ }^{a}$ & $62-80$ & 75 & 40.8 & 41.4 & -53.0 & 272.0 & 3.3 & Storetvedt et al. [1987] \\
\hline 6 & Cabo da Roca ${ }^{a}$ & $75-78$ & 75 & 39.4 & 43.4 & -54.0 & 272.0 & 6.2 & Storetvedt et al. [1987] \\
\hline 7 & Sintra Granites & $76-85$ & 80 & 359 & 43.5 & -76.5 & 354.0 & 5 & van der Voo [1969] \\
\hline 8 & Paço d'Ilhas sill & & 88 & 350.0 & 42.4 & -73.4 & 24.6 & 1.4 & This study \\
\hline 9 & Sintra Pluton (gabbros and diorites) ${ }^{a}$ & & 90 & 358.0 & 27.3 & -65.0 & 356.0 & 3.3 & Storetvedt et al. [1987] \\
\hline 10 & Organya Basin Sediments ${ }^{\mathrm{a}}$ & $100-84$ & 92 & 354,4 & 59.0 & -85.1 & 62.0 & 14,1 & Dinares-Turell and Garcia-Senz [2000] \\
\hline 11 & Organya Basin - Santa fè & $96.5-92.5$ & 94 & 357.7 & 47.2 & -76.0 & 9.6 & 2.1 & Gong et al. $[2008 \mathrm{a}]$ \\
\hline 12 & Foz da Fonte sill & & 94 & 346.5 & 44.3 & -73.8 & 37.1 & 3.1 & This study \\
\hline 13 & Lisbon Area Sediments ${ }^{\mathrm{a}}$ & $94-112$ & 103 & 358 & 53 & -85.0 & 9.7 & 9 & Galdeano et al. [1989] \\
\hline 14 & Organya Basin - Col d'Abella & $109-108$ & 108 & 356.0 & 48.1 & -76.5 & 16.4 & 2.7 & Gong et al. [2008a] \\
\hline 15 & Organya Basin - Lluçà & $112-109$ & 110 & 354.1 & 46.8 & -75 & 21.8 & 2.0 & Gong et al. [2008a] \\
\hline 16 & Algarve Basin Sediments & $125-100$ & 112 & 346.0 & 48.0 & -75.5 & 51.7 & 6,5 & Moreau et al. [1997] \\
\hline 17 & Organya Basin - Font Bordonera & $115-112$ & 114 & 342.4 & 51.7 & -72.9 & 61.6 & 1.1 & Gong et al. $[2008 \mathrm{a}]$ \\
\hline 18 & Organya Basin Sediments & 124-106 & 115 & 347.7 & 53.0 & -77.1 & 53.9 & 4,8 & Dinares-Turell and Garcia-Senz [2000] \\
\hline 19 & Organya Basin - Senyus top & $118-115$ & 116 & 348.4 & 56.3 & -79.6 & 64.0 & 1.6 & Gong et al. $[2008 \mathrm{a}]$ \\
\hline 20 & Lisbon Area Sediments & $125-112$ & 118 & 344.0 & 47.0 & -73.0 & 48.0 & 7.0 & Galdeano et al. [1989] \\
\hline 21 & Iberian Chain & $130-112$ & 120 & 345.5 & 44.5 & -71.3 & 44.5 & 7.0 & Moreau et al. [1992] \\
\hline 22 & Organya Basin - Senyus & $121-118$ & 121 & 334.9 & 56.5 & -70.1 & 84.6 & 1.3 & Gong et al. $[2008 \mathrm{a}]$ \\
\hline 23 & Organya Basin - Cabó & $124-121$ & 123 & 333.8 & 54.3 & -68.3 & 80.0 & 1.5 & Gong et al. $[2008 \mathrm{a}]$ \\
\hline 24 & Organya Basin Sediments & $126-124$ & 125 & 314.4 & 55.5 & -54.5 & 96.7 & 9.9 & Dinares-Turell and Garcia-Senz [2000] \\
\hline 25 & Organya Basin - Prada & $126-124$ & 125 & 308.8 & 57.5 & -51.3 & 102.8 & 1.1 & Gong et al. [2008a] \\
\hline 26 & Lisbon Area Sediments & $136-125$ & 130 & 317 & 58 & -57.0 & 95.0 & 4 & Galdeano et al. [1989] \\
\hline 27 & Organya Basin - Hostal Nou ${ }^{a}$ & $140-136$ & 138 & 290.6 & 59.1 & -39.1 & 113.4 & 1.7 & Gong et al. $[2008 \mathrm{a}]$ \\
\hline 28 & Algarve Basin Sediments & $151-136$ & 142 & 324.0 & 46.0 & -58.4 & 76.0 & 3.7 & Moreau et al. [1997] \\
\hline 29 & Algarve Limestones & $150-140$ & 145 & 328.0 & 45.9 & -61.4 & 71.6 & 3.9 & Galbrun et al. [1990] \\
\hline 30 & Iberian Ranges & $161-156$ & 159 & & & -57.4 & 70.5 & 3.8 & Steiner et al. [1985]; Juárez et al. [1998] \\
\hline
\end{tabular}

${ }^{\text {a}}$ Poles excluded for mean calculations.

100 to $88 \mathrm{Myr}$ interval (Figure 10a) than to the expected $\sim 73$ Ma position, suggesting an error in age dating. Indeed, recent dates for several LVC sites indicate that this volcanic episode may have lasted much longer than previously thought and begun at around $100 \mathrm{Ma}(\mathrm{R}$. Miranda, personal communication, 2011). The same argument applies to the Salema intrusion pole, for which a K-Ar whole-rock date gave an age of $72 \pm 2 \mathrm{Ma}$, but the palomagnetic pole position plots closer to the 125 to $100 \mathrm{Ma}$ interval (Figure 10a). Other poles were excluded because of their inconsistent position and shallow inclination (Figure 10a). These include the Sines, Cabo da Roca, Sintra Pluton (numbers 5, 6 and 9 [Storetvedt et al., 1987]), and Hostal Nou poles (number 27 [Gong et al., 2008a]). Finally, the Organyà basin (number 10 [Dinarès-Turell and Garcia-Senz, 2000]) and Lisbon area sediments (number 13 [Galdeano et al., 1989]) were not considered because of inconsistent pole positions and large $\alpha 95$ values (Table 2 and Figure 10a). Before this study, of the 20 poles selected (Figure 10b), only 3 were obtained from igneous rocks, while the rest were from sedimentary rocks. It is worth noting that between 100 and $88 \mathrm{Ma}$, only one selected pole, the Santa Fè sediments, Organyà Basin pole (number 11 [Gong et al., 2008a]), is reliable.

[34] Once plotted on our selected database, the PI and FF poles are observed to consistently fall between the 88-70 and 125-100 Ma intervals, but differ significantly from the Santa Fé pole (Organyà Basin, Pyrenees). We compared the PI and FF pole positions to the recent Global Apparent Polar Wander Path (GAPWP) of Torsvik et al. [2008] in African coordinates using the finite rotation poles listed in Table 3. The latter were calculated from the magnetic study made by Luis and Miranda [2008] up to chron C33r ( 83 Ma) for Iberia. During the Cretaceous superchron, it is not possible to compute intermediate finite rotation poles, and therefore we adopted the M0 rotation pole, determined by Olivet [1996], for our analysis. For the African-North American plate pair, we considered the finite rotation poles determined by Klitgord and Schouten [1986] up to chron 34, and the M0 rotation pole determined by Labails et al. [2010]. Both kinematic models were interpolated for the epochs under study (94 Ma and $88 \mathrm{Ma}$ ) to produce the two Iberian-African finite rotation parameters (Table 3). After rotation in African coordinates, the PI and FF pole positions plot close to the reference GAPWP of Torsvik et al. [2008] at 100 and $80 \mathrm{Ma}$ (Figure 10b).

[35] On the basis of the selected paleomagnetic pole positions, we discriminated time intervals for 160-136, 136$125,125-100,100-88$, and 88-70 Ma, and then calculated corresponding mean paleomagnetic poles (Figure 10c and Table 4). These mean poles show a coherent and quasi-linear path from 136 to $72 \mathrm{Ma}$, while during Jurassic-Cretaceous times (145-136 Ma) they depart westward. After rotating the mean poles into South African coordinates using selected and interpolated eulerian poles (Table 3), they fit with the GAPWP [Torsvik et al. [2008] for periods younger than $120 \mathrm{Ma}$. However, a significant misfit exists for older time intervals, i.e., those corresponding to rifting. The 136 to $125 \mathrm{Ma}$ interval is the most critical because, even without 
Table 3. Euler rotations for Iberia-Africa ${ }^{a}$

\begin{tabular}{|c|c|c|c|c|c|}
\hline $\begin{array}{l}\text { Longitude } \\
\text { (deg) }\end{array}$ & $\begin{array}{l}\text { Latitude } \\
\text { (deg) }\end{array}$ & $\begin{array}{l}\text { Angle } \\
\text { (deg) }\end{array}$ & $\begin{array}{l}\text { Age } \\
\text { (Ma) }\end{array}$ & Chrons & Reference \\
\hline \multicolumn{6}{|c|}{ Iberia - North America } \\
\hline 135.28 & 70.9 & -16.09 & 65 & $\mathrm{c} 29$ & Luis and Miranda [2008] \\
\hline 135.65 & 69.7 & -16.51 & 67 & c30 & Luis and Miranda [2008] \\
\hline 132.63 & 77.31 & -18.48 & 72 & c32 & Luis and Miranda [2008] \\
\hline 118.5 & 85.33 & -22.05 & 76 & c33 & Luis and Miranda [2008] \\
\hline 119.98 & 85.9 & -23.22 & 82 & $\mathrm{c} 33 \mathrm{r}$ & Luis and Miranda [2008] \\
\hline-9.4 & 76 & -42.6 & 125 & $\mathrm{~m} 0$ & Olivet $[1996]$ \\
\hline-7.4 & 73.1 & -52.1 & 203 & fit & Olivet [1996] \\
\hline \multicolumn{6}{|c|}{ North America-Africa } \\
\hline-0.63 & 82.51 & -20.96 & 65 & $\mathrm{c} 30$ & Klitgord and Schouten $[1986$ \\
\hline-9.15 & 81.35 & -22.87 & 71 & c32 & Klitgord and Schouten [1986] \\
\hline-11.76 & 80.76 & -23.91 & 73 & $\mathrm{c} 33 \mathrm{y}$ & Klitgord and Schouten [1986] \\
\hline-18.35 & 78.3 & -27.06 & 79 & c33o & Klitgord and Schouten [1986] \\
\hline-20.73 & 76.55 & -29.6 & 84 & $\mathrm{c} 34$ & Klitgord and Schouten [1986] \\
\hline-20.46 & 65.95 & -54.56 & 125 & mo & Labails [2007] \\
\hline-19.24 & 65.92 & -57.55 & 134 & $\mathrm{~m} 10 \mathrm{n}$ & Labails [2007] \\
\hline-18.08 & 66.57 & -59.34 & 142 & $\mathrm{~m} 16$ & Labails [2007] \\
\hline-18.7 & 66 & -62.29 & 148 & $\mathrm{~m} 21$ & Labails [2007] \\
\hline-18.44 & 66.08 & -62.8 & 150 & $\mathrm{~m} 22$ & Labails [2007] \\
\hline-15.86 & 67.1 & -70.55 & 154 & $\mathrm{~m} 25$ & Labails [2007] \\
\hline \multicolumn{6}{|c|}{ Iberia - Africa } \\
\hline-19.65 & 34.33 & 8.86 & 72 & & \\
\hline-16.2 & 31.12 & 9.6 & 88 & & \\
\hline-15.6 & 32.77 & 10.44 & 94 & & \\
\hline-13.87 & 34.08 & 12.81 & 111 & & \\
\hline-12.63 & 34.79 & 14.49 & 123 & & \\
\hline-11.44 & 37.07 & 15.63 & 130 & & \\
\hline-10.02 & 44.21 & 19.35 & 151 & & \\
\hline
\end{tabular}

${ }^{\mathrm{a}}$ Isochron ages have been corrected from the original publications using Gradstein et al. [2004]. Finite rotations were interpolated for the plate pairs Iberia-North America and Africa-North America, for the corresponding ages of the paleomagnetic samples, before the computation of the Iberia-Africa finite rotations.

rotation, the corresponding mean paleomagnetic pole is longitudinally distant from the GAPWP by $\sim 20^{\circ}$ eastward (Figure 10c). The use of alternative kinematic reconstructions for the Iberian and African plates does not show any improvement. One explanation for this is that, even if the GAPWP of Torsvik et al. [2008] is considered as the most reliable model for paleomagnetic reconstructions, it is not free of error. To test for such scenario, we plotted a recent compilation of African poles gathered by Font et al. [2009], which are only poles from igneous rocks, in order to minimize uncertainties in the paleomagnetic record of sedimentary rocks due to problems of inclination shallowing and time of magnetization acquisition. Figure 10e shows that despite their lower quality (i.e., large $\alpha 95$ angles) in comparison to the Iberian poles, the African mean pole at 140 to $110 \mathrm{Ma}$ is in agreement with the GAPWP [Torsvik et al., 2008]. A second explanation requires questioning the reliability of the paleomagnetic record for Iberia between 160 and $125 \mathrm{Ma}$, because it is based solely on six poles obtained from sedimentary rocks. It is worth noting that the misfit of the 160-125 Ma mean poles, in relation to the GAPWP, is essentially observed in the declination data set, suggesting that the magnetic inclination shallowing is not the principal source of error. Recent developments in the assessment of magnetic anomalies older than M0 west of Iberia [i.e., Bronner et al., 2011] show that a re-evaluation is needed to better constrain the early drifting of Iberia from North America, and to improve our understanding of the kinematics of the Bay of Biscay. Moreover, existing M0 and pre-M0 magnetic reconstructions always show some level of lithospheric overlap or gaps, never geologically justified by the identification of the corresponding compressive or extensive processes [e.g., Srivastava et al., 1990a]. In view of the available paleomagnetic data and seafloor magnetic anomalies, we are not able to solve this problem and future investigations in the interval of 160 to $125 \mathrm{Ma}$ are needed. For instance, kinematic models for Iberian Plate rotation, based on the declination and inclination of ChRM data [e.g., Gong et al., 2008a] are questionable until we are able to reconcile paleomagnetic data with seafloor magnetic anomalies.

\section{Conclusions}

[36] Our paleomagnetic and rock magnetic investigations provide two new key poles for Iberia at about 88 and $94 \mathrm{Ma}$, located at Lat $=73.4^{\circ}$; Long $=204.6^{\circ}\left(\mathrm{A} 95=1.3^{\circ}\right.$, $\mathrm{k}=42.7)$ and Lat $=73.8^{\circ}$; Long $=217.1^{\circ}\left(\mathrm{A} 95=3.3^{\circ}\right.$, $\mathrm{k}=26$ ), respectively. Once rotated into South African coordinates using our selected and interpolated eulerian poles, they match the global Apparent Polar Wander Path at 80-100 Ma. On the basis of a rigorous selection of Cretaceous paleomagnetic poles from Iberia, we calculated mean paleomagnetic poles to test paleogeographic reconstructions. We conclude that from 120 to $70 \mathrm{Ma}$, paleomagnetic poles and magnetic anomaly reconstruction, when taken together, match well the global APWP, but are inconsistent when considering the interval of 160-120 Ma. Consequently, a coherent kinematic model for the Iberia rotation from 160 to 70 Ma will only feasible after we are able to reconcile

Table 4. Mean Cretaceous Paleomagnetic Poles for Iberia and Iberia-Africa Finite Rotation Euler Poles ${ }^{\mathrm{a}}$

\begin{tabular}{|c|c|c|c|c|c|c|c|c|c|c|c|}
\hline & \multicolumn{6}{|c|}{ Mean Cretaceous Paleomagnetic Poles of Iberia } & \multicolumn{5}{|c|}{ Euler Poles (Iberia-Africa) } \\
\hline & $\begin{array}{l}\text { Age } \\
(\mathrm{Ma})\end{array}$ & $\begin{array}{l}\text { Latitude } \\
\text { (deg) }\end{array}$ & $\begin{array}{l}\text { Longitude } \\
\text { (deg) }\end{array}$ & a95 & $\mathrm{N}$ & $\begin{array}{l}\text { Pole } \\
\text { Number }\end{array}$ & $\begin{array}{l}\text { Age } \\
\text { (Ma) }\end{array}$ & $\begin{array}{l}\text { Longitude } \\
\quad \text { (deg) }\end{array}$ & $\begin{array}{l}\text { Latitude } \\
\text { (deg) }\end{array}$ & $\begin{array}{l}\text { Angle } \\
\text { (deg) }\end{array}$ & Reference \\
\hline \multirow[t]{2}{*}{ Late Cretaceous } & $70-88$ & -75.6 & 351.6 & 3.9 & 3 & $3-4 ; 7$ & 72 & -19.65 & 34.33 & 8.86 & $\begin{array}{l}\text { Luis and Miranda }[2008] ; \\
\text { Klitgord and Schouten }[1986]\end{array}$ \\
\hline & $88-100$ & -75.1 & 22.6 & 2.8 & 5 & $8 ; 11-12 ; 14-15$ & 94 & -15.6 & 32.77 & 10.44 & $\begin{array}{l}\text { Luis and Miranda }[2008] \text {; } \\
\text { Klitgord and Schouten }[1986]\end{array}$ \\
\hline \multirow[t]{4}{*}{ Early Cretaceous } & $100-120$ & -75.6 & 53.1 & 3 & 6 & $16-21$ & 111 & -13.87 & 34.08 & 12.81 & Olivet [1996]; Labails [2007] \\
\hline & $120-125$ & -69.2 & 82.2 & 5.3 & 2 & $22-23$ & 123 & -12.63 & 34.79 & 14.49 & Olivet [1996]; Labails [2007] \\
\hline & $125-136$ & -54.3 & 98.3 & 5.7 & 3 & $24-26$ & 130 & -11.44 & 37.07 & 15.63 & Olivet [1996]; Labails [2007] \\
\hline & $136-160$ & -59 & 72.8 & 4 & 3 & $28-30$ & 151 & -10.02 & 44.21 & 19.35 & Olivet [1996]; Labails [2007] \\
\hline
\end{tabular}

\footnotetext{
${ }^{\mathrm{a}}$ See text for details.
} 
paleomagnetic data set with kinematics of Iberia-Africa plate pair for the 160-120 Ma period.

[37] Acknowledgments. This work was performed as part of the $\mathrm{PhD}$ work of Marta Neres (Instituto Dom Luiz, Universidade de Lisboa) on a grant from FCT (Fundação para a Ciência e Tecnologia, Portuguese Government; SFRH/BD/61633/2009). Additional funds were provided by the Fundação Calouste Gulbenkian (Prémio Gulbenkian de Estímulo à Investigação 2010), TOPOMED (Plate reorganization in the Western Mediterranean: lithospheric causes and topographic consequences, TOPOEUROPE/ 0001/2007), TECTAP (Structure, stratigraphy and Tectono-thermal evolution of the Tagus Abyssal Pain, PTDC/CTE-GIN/68462/2006) and by the Instituto Dom Luiz (Pest-OE/CTE/LA0019/2011-IDL). We are indebted to Luis Alva-Valdivia for making possible the FORC measurements and to Philipe de Perceval, Souphie Gouy, and Thierry Aigouy for SEM observations of FF samples. The authors thank Alicia Palencia-Ortas, Anne Nédélec, Jacques Rey, Jean-Luc Bouchez, José Carlos Kullberg, Mário Moreira, Pedro Silva, and Vicente Ruiz-Martinez for fruitful discussions. We particularly thank Brooks B. Ellwood for help in English. We also acknowledge the constructive reviews of the Associate Editor Stuart Gilder and reviewers Rob van der Voo and Jaume Dinarèz-Turell, who helped to improve our manuscript

\section{References}

Afilhado, A., L. Matias, H. Shiobara, A. Hirn, L. Mendes-Victor, and H. Shimamura (2008), From unthinned continent to ocean: The deep structure of the West Iberia passive continental margin at 38 degrees N, Tectonophysics, 458(1-4), 9-50, doi:10.1016/j.tecto.2008.03.002.

Bernard-Griffiths, J., G. Gruau, G. Cornen, B. Azambre, and J. Mace (1997), Continental lithospheric contribution to alkaline magmatism Isotopic $(\mathrm{Nd}, \mathrm{Sr}, \mathrm{Pb})$ and geochemical (REE) evidence from Serra de Monchique and Mount Ormonde complexes, J. Petrol., 38(1), 115-132, doi:10.1093/petroj/38.1.115.

Besse, J., and V. Courtillot (2002), Apparent and true polar wander and the geometry of the geomagnetic field over the last $200 \mathrm{Myr}, J$. Geophys. Res., 107(B11), 2300, doi:10.1029/2000JB000050.

Biggin, A. J., D. J. J. van Hinsbergen, C. G. Langereis, G. B. Straathof, and M. H. L. Deenen (2008), Geomagnetic secular variation in the Cretaceous Normal Superchron and in the Jurassic, Phys. Earth Planet. Inter., 169(1-4), 3-19, doi:10.1016/j.pepi.2008.07.004.

Bronner, A., D. Sauter, G. Manatschal, G. Peron-Pinvidic, and M. Munschy (2011), Magmatic breakup as an explanation for magnetic anomalies at magma-poor rifted margins, Nat. Geosci., 4(8), 549-553, doi:10.1038/ ngeo1201

Bullard, E., J. Everett, and A. Gilbert Smith (1965), A symposium on continental drift, Philos. Trans. R. Soc. A., 258, 41-51.

Carey, S. W. (1958), A tectonic approach to continental drift, in Symposium on Continental Drift, edited by P. M. S. Blackett et al., pp. 177-355, R. Soc., London.

Chadima, M., and F. Hrouda (2006), Remasoft 3.0 a user-friendly paleomagnetic data browser and analyzer, Trav. Géophys., XXVII, 20-21.

Cloetingh, S., J. Gallart, G. de Vicente, and L. Matenco (2011), TOPOEUROPE: From Iberia to the Carpathians and analogues, Tectonophysics, 502(1-2), 1-27, doi:10.1016/j.tecto.2010.11.008.

Cox, A. (1970), Latitude dependence of the angular dispersion of the geomagnetic field, Geophys. J. R. Astron. Soc., 20, 253-269, doi:10.1111/ j.1365-246X.1970.tb06069.x.

Deenen, M. H. L., C. G. Langereis, D. J. J. van Hinsbergen, and A. J. Biggin (2011), Geomagnetic secular variation and the statistics of palaeomagnetic directions, Geophys. J. Int., 186(2), 509-520, doi:10.1111/j.1365246X.2011.05050.x

Dinarès-Turell, J., and J. Garcia-Senz (2000), Remagnetization of Lower Cretaceous limestones from the southern Pyrenees and relation to the Iberian plate geodynamic evolution, J. Geophys. Res., 105(B8), 19,405-19,418, doi:10.1029/2000JB900136.

Dinis, J. L., J. Rey, P. P. Cunha, P. Callapez, and R. Pena dos Reis (2008), Stratigraphy and allogenic controls of the western Portugal Cretaceous: An updated synthesis, Cretaceous Res., 29(5-6), 772-780, doi:10.1016/ j.cretres.2008.05.027.

Dunlop, D. J. (2002a), Theory and application of the Day plot (M-rs/M-s versus $\mathrm{H}-\mathrm{cr} / \mathrm{H}-\mathrm{c})$ : 1 . Theoretical curves and tests using titanomagnetite data, J. Geophys. Res., 107(B3), 2056, doi:10.1029/2001JB000486.

Dunlop, D. J. (2002b), Theory and application of the Day plot (M-rs/M-s versus $\mathrm{H}-\mathrm{cr} / \mathrm{H}-\mathrm{c})$ : 2. Application to data for rocks, sediments, and soils, J. Geophys. Res., 107(B3), 2057, doi:10.1029/2001JB000487.

Dunlop, D. J., and O. Ozdemir (1997), Rock Magnetism: Fundamentals and Frontiers, Cambridge Univ. Press, Cambridge, U. K., doi:10.1017/ CBO9780511612794.
Ferreira, M. R. P., and C. R. Macedo (1979), K-Ar Ages of the PermianMesozoic Basaltic activity in Portugal, Eur. Col. Geochron. Cosmochron. Isotope Geol., 6, 26-27.

Fisher, R. (1953), Dispersion on a sphere, Proc. R. Soc. A, 217(1130), 295-305, doi:10.1098/rspa.1953.0064

Font, E., R. I. F. Trindade, and A. Nedelec (2006), Remagnetization in bituminous limestones of the Neoproterozoic Araras Group (Amazon craton) Hydrocarbon maturation, burial diagenesis, or both?, J. Geophys. Res., 111(B6), B06204, doi:10.1029/2005JB004106.

Font, E., M. Ernesto, P. F. Silva, P. B. Correia, and M. A. L. Nascimento (2009), Palaeomagnetism, rock magnetism and AMS of the Cabo Magmatic Province, NE Brazil, and the opening of South Atlantic, Geophys. J. Int., 179(2), 905-922, doi:10.1111/j.1365-246X.2009.04333.x.

Font, E., C. Nascimento, R. Omira, M. A. Baptista, and P. F. Silva (2010), Identification of tsunami-induced deposits using numerical modeling and rock magnetism techniques: A study case of the 1755 Lisbon tsunami in Algarve, Portugal, Phys. Earth Planet. Inter., 182(1-2), 187-198.

Fuller, M. S. Cisowski, M. Hart, R. Haston, E. Schmidtke, and R. Jarrard (1988), NRM-IRM(s) demagnetization plots : An aid to the interpretation of natural remanent magnetization, Geophys. Res. Lett., 15(5), 518-521, doi:10.1029/GL015i005p00518

Fuller, M., T. Kidane, and J. Ali (2002), AF demagnetization characteristics of NRM, compared with anhysteretic and saturation isothermal remanence: An aid in the interpretation of NRM, Phys. Chem. Earth, 27(25-31), 1169-1177, doi:10.1016/s1474-7065(02)00127-4.

Galbrun, B., P. Y. Berthou, C. Moussin, and J. Azema (1990), Magnetostratigraphy of the Jurassic-Cretaceous boundary in carbonate marine shelf: The Bias do Norte section (Algarve, Portugal), Bull. Soc. Geol. Fr., 6(1), 133-143.

Galdeano, A., M. G. Moreau, J. P. Pozzi, P. Y. Berthou, and J. A. Malod (1989), New paleomagnetic results from Cretaceous sediments near Lisbon (Portugal) and implications for the rotation of Iberia, Earth Planet. Sci. Lett., 92(1), 95-106, doi:10.1016/0012-821X(89)90024-1.

Gong, Z., C. G. Langereis, and T. A. T. Mullender (2008a), The rotation of Iberia during the Aptian and the opening of the Bay of Biscay, Earth Planet. Sci. Lett., 273(1-2), 80-93, doi:10.1016/j.epsi.2008.06.016.

Gong, Z., M. J. Dekkers, J. Dinarès-Turell, and T. A. T. Mullender (2008b), Remagnetization mechanism of Lower Cretaceous rocks from the Organya Basin (Pyrenees, Spain), Stud. Geophys. Geod., 52(2), 187-210, doi:10.1007/s11200-008-0013-3.

Gong, Z., D. J. J. van Hinsbergen, and M. J. Dekkers (2009), Diachronous pervasive remagnetization in northern Iberian basins during Cretaceous rotation and extension, Earth Planet. Sci. Lett., 284(3-4), 292-301, doi:10.1016/j.epsl.2009.04.039.

Gradstein, F. M., J. G. Ogg, and A. G. Smith (2004), A geologic time scale 2004, Lethaia, 37(2), 175-181, doi:10.1080/00241160410006483.

Grange, M., U. Scharer, G. Cornen, and J. Girardeau (2008), First alkaline magmatism during Iberia-Newfoundland rifting, Terra Nova, 20(6), 494-503, doi:10.1111/j.1365-3121.2008.00847.x.

Grange, M., U. Scharer, R. Merle, J. Girardeau, and G. Cornen (2010), Plume-lithosphere interaction during migration of Cretaceous alkaline magmatism in SW Portugal: Evidence from $\mathrm{U}-\mathrm{Pb}$ ages and $\mathrm{Pb}-\mathrm{Sr}-\mathrm{Hf}$ isotopes, J. Petrol., 51(5), 1143-1170, doi:10.1093/petrology/egq018.

Haggerty, S. E. (1991), Oxide textures: A mini-atlas, in Oxide Minerals: Petrologic and Magnetic Significance, edited by D. H. Lindsley, Rev. Mineral., 25, 129-219.

Harrison, R. J., and J. M. Feinberg (2008), FORCinel: An improved algorithm for calculating first-order reversal curve distributions using locally weighted regression smoothing, Geochem. Geophys. Geosyst., 9, Q05016, doi:10.1029/2008GC001987.

Heslop, D., G. McIntosh, and M. J. Dekkers (2004), Using time- and temperature-dependent Preisach models to investigate the limitations of modelling isothermal remanent magnetization acquisition curves with cumulative log Gaussian functions, Geophys. J. Int., 157(1), 55-63, doi:10.1111/j.1365-246X.2004.02155.x.

Hoffman, K. A., B. S. Singer, P. Camps, L. N. Hansen, K. A. Johnson, S. Clipperton, and C. Carvallo (2008), Stability of mantle control over dynamo flux since the mid-Cenozoic, Phys. Earth Planet. Inter. 169(1-4), 20-27, doi:10.1016/j.pepi.2008.07.012.

Irving, E., and M. A. Ward (1964), A statistical model of the geomagnetic field, Pure Appl. Geophys., 57, 47-52, doi:10.1007/BF00879707.

Jackson, M., W. W. Sun, and J. P. Craddock (1992), The rock magnetic fingerprint of chemical remagnetization in midcontinental Paleozoic carbonates, Geophys. Res. Lett., 19(8), 781-784, doi:10.1029/92GL00832.

Jackson, M., P. Rochette, G. Fillion, S. Banerjee, and J. Marvin (1993), Rock magnetism of remagnetized Paleozoic carbonates - low-temperature behavior and susceptibility characteristics, J. Geophys. Res., 98(B4), 6217-6225, doi:10.1029/92JB01319. 
Juárez, M. T., M. L. Osete, G. Melendez, C. G. Langereis, and J. D. A. Zijderveld (1994), Oxfordian magnetostratigraphy of the Aguilon and Tosos sections (Iberian Range, Spain) and evidence of a Preoligocene overprint, Phys. Earth Planet. Inter., 85(1-2), 195-211, doi:10.1016/ 0031-9201(94)90017-5.

Juárez, M. T., W. Lowrie, M. L. Osete, and G. Melendez (1998), Evidence of widespread Cretaceous remagnetisation in the Iberian Range and its relation with the rotation of Iberia, Earth Planet. Sci. Lett., 160(3-4), 729-743, doi:10.1016/S0012-821X(98)00124-1.

Kirschvink, J. L. (1980), The least-squares line and plane and the analysis of paleomagnetic data, Geophys. J. R. Astron. Soc., 62(3), 699-718, doi:10.1111/j.1365-246X.1980.tb02601.x.

Klitgord, K. D., and H. Schouten (1986), Plate kinematics of the central Atlantic, in Geology of North America, edited by P. R. Vogt et al. pp. 351-378, Geol. Soc. Am., Boulder, Colo.

Kruiver, P. P., M. J. Dekkers, and D. Heslop (2001), Quantification of magnetic coercivity components by the analysis of acquisition curves of isothermal remanent magnetisation, Earth Planet. Sci. Lett., 189(3-4), 269-276, doi:10.1016/S0012-821X(01)00367-3.

Kruiver, P. P., C. G. Langereis, M. J. Dekkers, and W. Krijgsman (2003), Rock-magnetic properties of multicomponent natural remanent magnetization in alluvial red beds (NE Spain), Geophys. J. Int., 153(2), 317-332, doi:10.1046/j.1365-246X.2003.01880.x

Labails, C. (2007), La marge sud-marocaine et les premières phases d'ouverture de l'océan Atlantique central, $\mathrm{PhD}$ thesis, 135 pp., Univ. de Bretagne Occident., Brest, France.

Labails, C., J. L. Olivet, D. Aslanian, and W. R. Roest (2010), An alternative early opening scenario for the Central Atlantic Ocean, Earth Planet Sci. Lett., 297(3-4), 355-368, doi:10.1016/j.epsl.2010.06.024.

Le Pichon, X., and J. C. Sibuet (1971), Comments on the evolution of North-East Atlantic, Nature, 233(5317), 257-258, doi:10.1038/233257a0.

Linder, J., and S. A. Gilder (2012), Latitude dependency of the geomagnetic secular variation S parameter: A mathematical artifact, Geophys. Res. Lett., 39, L02308, doi:10.1029/2011GL050330.

Lowrie, W. (1990), Identification of ferromagnetic minerals in a rock by coercivity and unblocking temperature properties, Geophys. Res. Lett. 17(2), 159-162, doi:10.1029/GL017i002p00159.

Luis, J. F., and J. M. Miranda (2008), Reevaluation of magnetic chrons in the North Atlantic between $35^{\circ} \mathrm{N}$ and $47^{\circ} \mathrm{N}$ : Implications for the formation of the Azores Triple Junction and associated plateau, J. Geophys Res., 113, B10105, doi:10.1029/2007JB005573.

Macintyre, R. M., and G. W. Berger (1982), A note on the geochronology of the Iberian alkaline province, Lithos, 15(2), 133-136, doi:10.1016/ 0024-4937(82)90005-6.

Mahmoudi, A. (1991), Quelques intrusions alcalines et basiques du Cretacé Superieur au Portugal, PhD thesis, Univ. Nancy I, Nancy, France.

Martins, L. T. (1991), Actividade Ignea Mesozóica em Portugal, PhD thesis, Fac. de Ciênc., Univ. de Lisboa, Lisbon.

Martins, L. T., J. Madeira, N. Youbi, J. Munha, J. Mata, and R. Kerrich (2008), Rift-related magmatism of the central Atlantic magmatic province in Algarve, southern Portugal, Lithos, 101(1-2), 102-124, doi:10.1016/j. lithos.2007.07.010.

Márton, E., M. C. Abranches, and J. Pais (2004), Iberia in the Cretaceous: New paleomagnetic results from Portugal, J. Geodyn., 38(2), 209-221, doi:10.1016/j.jog.2004.06.004.

McCabe, C., and R. D. Elmore (1989), The occurrence and origin of late Paleozoic remagnetization in the sedimentary-rocks of North-America, Rev. Geophys., 27(4), 471-494, doi:10.1029/RG027i004p00471.

McFadden, P. L., R. T. Merrill, and M. W. McElhinny (1988), Dipole / quadrupole family modelling of paleosecular variation, J. Geophys. Res., 93(B10), 11,583-11,588, doi:10.1029/JB093iB10p11583.

Merrill, R. T., and P. L. McFadden (2003), The geomagnetic axial dipole field assumption, Phys. Earth Planet. Inter., 139(3-4), 171-185, doi:10.1016/j.pepi.2003.07.016

Miranda, R. (2010), Petrogenesis and geochronology of the Late Cretaceous alkaline magmatism in the west Iberian Margin, PhD thesis, $366 \mathrm{pp}$. Univ. of Lisbon, Lisbon.

Miranda, R., V. Valadares, P. Terrinha, J. Mata, M. R. Azevedo, M. Gaspar, J. C. Kullberg, and C. Ribeiro (2009), Age constraints on the Late Cretaceous alkaline magmatism on the West Iberian Margin, Cretaceous Res., 30(3), 575-586, doi:10.1016/j.cretres.2008.11.002.

Moreau, M. G., J. Canerot, and J. A. Malod (1992), Paleomagnetic study of Mesozoic sediments from the Iberian chain (Spain) suggestions for Barremian remagnetization and implications for the rotation of Iberia, Bull. Soc. Geol. Fr., 163(4), 393-402.

Moreau, M. G., J. Y. Berthou, and J. A. Malod (1997), New paleomagnetic Mesozoic data from the Algarve (Portugal): Fast rotation of Iberia between the Hauterivian and the Aptian, Earth Planet. Sci. Lett., 146(3-4), 689-701, doi:10.1016/S0012-821X(96)00239-7.
Neves, M. C., R. Terrinha, A. Afilhado, M. Moulin, L. Matias, and F. Rosas (2009), Response of a multi-domain continental margin to compression: Study from seismic reflection-refraction and numerical modelling in the Tagus Abyssal Plain, Tectonophysics, 468(1-4), 113-130, doi:10.1016/ j.tecto.2008.05.008

Olivet, J. L. (1996), Kinematics of the Iberian Plate, Bull. Cent. Rech. Explor. Prod. Elf Aquitaine, 20(1), 131-195.

Omira, R., M. A. Baptista, and J. M. Miranda (2011), Evaluating tsunami impact on the Gulf of Cadiz coast (northeast Atlantic), Pure Appl. Geophys., 168(6-7), 1033-1043, doi:10.1007/s00024-010-0217-7.

Osete, M. L., and A. Palencia Ortas (2006), Polos paleomagnéticos de los últimos 300 millones de años, Fís. Tierra, 18, 157-181.

Osete, M. L., J. J. Gomez, F. J. Pavon-Carrasco, J. J. Villalain, A. PalenciaOrtas, V. C. Ruiz-Martinez, and F. Heller (2011), The evolution of Iberia during the Jurassic from palaeomagnetic data, Tectonophysics, 502(1-2), 105-120, doi:10.1016/j.tecto.2010.05.025.

Robertson, D. J., and D. E. France (1994), Discrimination of remanencecarrying minerals in mixtures, using isothermal remanent magnetization acquisition curves, Phys. Earth Planet. Inter., 82(3-4), 223-234, doi:10.1016/0031-9201(94)90074-4.

Rock, N. M. S. (1982), The late Cretaceous alkaline igneous province in the Iberian Peninsula, and its tectonic significance, Lithos, 15(2), 111-131, doi:10.1016/0024-4937(82)90004-4.

Rosenbaum, G., G. S. Lister, and C. Duboz (2002), Relative motions of Africa, Iberia and Europe during Alpine orogeny, Tectonophysics, 359(1-2), 117-129, doi:10.1016/S0040-1951(02)00442-0.

Russell, S. M., and R. B. Whitmarsh (2003), Magmatism at the west Iberia non-volcanic rifted continental margin: Evidence from analyses of magnetic anomalies, Geophys. J. Int., 154(3), 706-730, doi:10.1046/ j.1365-246X.2003.01999.x.

Schettino, A., and C. R. Scotese (2005), Apparent polar wander paths for the major continents (200 Ma to the present day): A palaeomagnetic reference frame for global plate tectonic reconstructions, Geophys. J. Int., 163(2), 727-759, doi:10.1111/j.1365-246X.2005.02638.x.

Schott, J. J., and A. Peres (1987), Paleomagnetism of the lower Cretaceous redbeds from northern Spain: Evidence for a multistage acquisition of magnetization, Tectonophysics, 139(3-4), 239-253, doi:10.1016/00401951(87)90099-0.

Scotese, C. R., L. M. Gahagan, and R. L. Larson (1988), Plate tectonic reconstructions of the Cretaceous and Cenozoic ocean basins, Tectonophysics, 155(1-4), 27-48, doi:10.1016/0040-1951(88)90259-4.

Sibuet, J. C., S. P. Srivastava, and W. Spakman (2004), Pyrenean orogeny and plate kinematics, J. Geophys. Res., 109, B08104, doi:10.1029/ 2003JB002514

Sibuet, J. C., S. Srivastava, and G. Manatschal (2007), Exhumed mantleforming transitional crust in the Newfoundland-Iberia rift and associated magnetic anomalies, J. Geophys. Res., 112, B06105, doi:10.1029/ 2005JB003856.

Srivastava, S. P., W. R. Roest, L. C. Kovacs, G. Oakey, S. Levesque, J. Verhoef, and R. Macnab (1990a), Motion of Iberia since the late Jurassic: Results from detailed aeromagnetic measurements in the Newfoundland basin, Tectonophysics, 184(3-4), 229-260, doi:10.1016/ 0040-1951(90)90442-B

Srivastava, S. P., H. Schouten, W. R. Roest, K. D. Klitgord, L. C. Kovacs, J. Verhoef, and R. Macnab (1990b), Iberian Plate kinematics: A jumping plate boundary between Eurasia and Africa, Nature, 344(6268), 756-759, doi:10.1038/344756a0

Srivastava, S. P., J. C. Sibuet, S. Cande, W. R. Roest, and I. D. Reid (2000), Magnetic evidence for slow seafloor spreading during the formation of the Newfoundland and Iberian margins, Earth Planet. Sci. Lett., 182(1), 61-76, doi:10.1016/S0012-821X(00)00231-4.

Steiner, M. B., J. G. Ogg, G. Melendez, and L. Sequeiros (1985), Jurassic magnetostratigraphy. 2. Middle-late Oxfordian of Aguilon, Iberian Cordillera, northern Spain, Earth Planet. Sci. Lett., 76(1-2), 151-166, doi:10.1016/0012-821X(85)90155-4.

Storetvedt, K. M., H. Mogstad, M. C. Abranches, J. G. Mitchell, and A. Serralheiro (1987), Paleomagnetism and isotopic age data from upper Cretaceous igneous rocks of W Portugal: Geological correlation and plate tectonic aspects, Geophys. J. R. Astron. Soc., 88(1), 241-263, doi:10.1111/ j.1365-246X.1987.tb01378.x.

Storetvedt, K. M., J. G. Mitchell, M. C. Abranches, and S. Oftedahl (1990), A new kinematic model for Iberia: Further paleomagnetic and isotopic age evidence, Phys. Earth Planet. Inter., 62(1-2), 109-125, doi:10.1016/ 0031-9201(90)90196-5.

Tauxe, L., and D. V. Kent (2004), A simplified statistical model for the geomagnetic field and the detection of shallow bias in paleomagnetic inclinations: Was the ancient magnetic field dipolar?, in Timescales of the Paleomagnetic Field, edited by J. E. T. Channell et al., pp. 101-115, AGU, Washington, D. C., doi:10.1029/145GM08. 
Torsvik, T. H., R. D. Mueller, R. van der Voo, B. Steinberger, and C. Gaina (2008), Global plate motion frames: Toward a unified model, Rev. Geophys., 46, RG3004, doi:10.1029/2007RG000227.

Tucholke, B. E., D. S. Sawyer, and J. C. Sibuet (2007), Breakup of the Newfoundland-Iberia rift, Geol. Soc. Spec. Publ., 282, 9-46.

van der Voo, R. (1969), Paleomagnetic evidence for the rotation of the Iberian Peninsula, Tectonophysics, 7, 5-56, doi:10.1016/0040-1951(69) 90063-8.

van der Voo, R. (1990), The reliability of paleomagnetic data, Tectonophysics, 184(1), 1-9, doi:10.1016/0040-1951(90)90116-P.

van der Voo, R., and J. D. A. Zijderveld (1971), Renewed paleomagnetic study of Lisbon volcanics and implications for rotation of Iberian Peninsula, J. Geophys. Res., 76(17), 3913-3921, doi:10.1029/JB076i017p03913.
Verati, C., C. Rapaille, G. Feraud, A. Marzoli, H. Bertrand, and N. Youbi (2007), (40)Ar/(39)Ar ages and duration of the central Atlantic magmatic province volcanism in Morocco and Portugal and its relation to the TriassicJurassic boundary, Palaeogeogr. Palaeoclimatol. Palaeoecol., 244(1-4), 308-325, doi:10.1016/j.palaeo.2006.06.033.

Villalain, J. J., G. Fernadez-Gonzalez, A. M. Casas, and A. Gil-Imaz (2003), Evidence of a Cretaceous remagnetization in the Cameros Basin (north Spain): Implications for basin geometry, Tectonophysics, 377(1-2), 101-117, doi:10.1016/j.tecto.2003.08.024.

Vissers, R. L. M., and P. T. Meijer (2012), Mesozoic rotation of Iberia: Subduction in the Pyrenees?, Earth Sci. Rev., 110(1-4), 93-110, doi:10.1016/ j.earscirev.2011.11.001 